\title{
Complexities of coastal shark movements and their implications for management
}

\author{
Conrad W. Speed ${ }^{1,2, *}$, Iain C. Field ${ }^{3}$, Mark G. Meekan ${ }^{1}$, Corey J. A. Bradshaw ${ }^{4,5}$ \\ ${ }^{1}$ Australian Institute of Marine Science, UWA Oceans Institute (MO96), 35 Stirling Highway, Crawley, \\ Western Australia 6009, Australia \\ ${ }^{2}$ School for Environmental Research, Charles Darwin University, Darwin, Northern Territory 0909, Australia \\ ${ }^{3}$ Graduate School for the Environment, Macquarie University, Sydney, New South Wales 2109, Australia \\ ${ }^{4}$ The Environment Institute and School of Earth and Environmental Sciences, University of Adelaide, Adelaide, \\ South Australia 5005, Australia \\ ${ }^{5}$ South Australian Research and Development Institute, PO Box 120, Henley Beach, South Australia 5022, Australia
}

\begin{abstract}
Global declines of shark populations are of concern because of their largely assumed role as moderators of ecosystem function. Without long-term data on movement patterns for many species, it is impossible to infer relative extinction risk, which varies as a function of range, dispersal and habitat specificity and use. The past $50 \mathrm{yr}$ of research on coastal sharks has revealed common movement patterns among species. In the horizontal plane, measured home range size generally increases with body size. We demonstrate meta-analytically the effects of increasing body size and monitoring time on home range size. Changes in the extent of horizontal movement might arise from ontogeny, predator avoidance or environmental tolerances. In the vertical plane, movement patterns include oscillatory vertical displacement, surface swimming, diel vertical migration and swimming at depth. These vertical movements are often attributed to foraging or navigation, but have been quantified less than horizontal patterns. Habitat specificity is often correlated with environmental conditions such as depth, salinity, substratum, and in some cases, prey availability. Site fidelity is common in species that use nursery areas. However, fidelity to mating, pupping, feeding and natal sites has only been observed in a few species. To date, few studies have examined habitat partitioning, although some general patterns have emerged: habitats appear to be subdivided by benthos type, prey availability and depth. The conservation of coastal sharks can be facilitated in some cases by the use of marine protected areas, especially for coastal resident species using specific nursery, reproduction or feeding areas. Partial protected-area closures might be effective during aggregation or migration periods to protect older size classes, but these must be applied with other management strategies such as reduced fishing and size or bag limits to protect individuals throughout different life history phases. More long-term research on habitat use, migration patterns and habitat partitioning is essential for developing successful management initiatives for coastal shark populations.
\end{abstract}

KEY WORDS: Extinction risk $\cdot$ Depth range $\cdot$ Habitat loss $\cdot$ Harvest $\cdot$ Home range $\cdot$ Horizontal range $\cdot$ Life history $\cdot$ Ontogeny $\cdot$ Segregation $\cdot$ Site fidelity $\cdot$ Vertical migration $\cdot$ Habitat partitioning

\section{INTRODUCTION}

Sharks are typically high trophic level predators in marine food webs (Cortes 1999a), so they assist in structuring biological communities (e.g. Stevens et al. 2000a, Myers \& Worm 2003, Bascompte et al. 2005,
Shepherd \& Myers 2005, Myers et al. 2007). Their capacity to influence community composition and relative abundance of prey species likely provides trophic stability over some time scales, and this capacity is in itself affected by habitat use, movement and distribution patterns. Sharks directly affect community compo- 
sition by prey ingestion, and indirectly through predation risk (e.g. Heithaus et al. 2008). The reduction in shark density can lead to the release of mesopredator populations (Myers et al. 2007), an increase in competing taxa (e.g. Fogarty \& Murawski 1998) and ultimately, a reduction or imbalance in species under the influence of predation (Pace et al. 1999). In some cases, the removal or large density reduction of sharks can reduce ecosystem stability and resilience, which could result in cascading effects that lead to population declines in other parts of the food web (Jackson et al. 2001, Myers et al. 2007, but see Bascompte et al. 2005). However, the correlative and theoretical nature of many studies leaves some uncertainty over the likely effects of reduced shark density on marine ecosystem function.

Despite the purported functional and behavioural importance of sharks to marine ecosystems, aspects of their biology and ecology remain poorly understood due to difficulties in obtaining in situ data (Nelson 1977, Sundström et al. 2001). The biological traits that make them particularly vulnerable to exploitation (i.e. relatively slow growth rates, late sexual maturity and reproduction, low fecundity and long gestation periods; Compagno 1990, Cortes 2000) can lead to slow population growth and limit compensatory responses to exploitation for some species (Musick et al. 2000, Field et al. 2009). The risk of extinction might also be exacerbated by habitat specificity and limited distribution or dispersal (Walker 1998, Stevens et al. 2000a), with the strength of effect often depending on the environmental context (Brook et al. 2008, Garcia et al. 2008, Field et al. 2009).

Coastal shark populations are particularly vulnerable to harvest due to their proximity to human populations, where fishing pressure and habitat degradation are typically high (e.g. Holland et al. 1999). For example, over-exploitation has led to declines in abundances of sharks on some tropical reefs (e.g. Friedlander \& DeMartini 2002, Robbins et al. 2006, Sandin et al. 2008, Heupel et al. 2009). Moreover, habitat degradation and the myriad effects of climate change will be most severe in coastal areas where sharks with specific nursery or breeding requirements are particularly vulnerable; however, the resilience of sharks to climate change remains largely unquantified (Field et al. 2009).

A common ecological trait of many shark species likely to influence their susceptibility to exploitation is their tendency to segregate by size and sex (Springer 1967, Kinney \& Simpfendorfer 2009). Many use inshore areas as nurseries (Castro 1993, Yokota \& Lessa 2006, Heupel et al. 2007), while others are segregated within similar habitats by sex (Sims 2005) for reasons related to parturition (Hight \& Lowe 2007), or segre- gated by size due to habitat selection (e.g. Simpfendorfer et al. 2005). The belief that shark nursery areas are essential for population persistence (Bonfil 1997) has placed a focus on the study of juvenile life stages (Heupel et al. 2007, Kinney \& Simpfendorfer 2009), which has also been facilitated by the relative ease of handling juveniles and access. However, following departure from nursery areas, the movement and habitat use of larger juveniles, subadults and adults are often unknown (but see Chapman et al. 2009). This has particular relevance for management strategies such as the design of marine protected areas, because for these large, free-ranging predators, protected area effectiveness can be compromised if individuals spend considerable time outside their boundaries (Chapman et al. 2005, Meekan et al. 2006, Kinney \& Simpfendorfer 2009).

In the last decade, the development and accessibility of tracking and passive monitoring technology (e.g. Heupel et al. 2006a) has increased the tractability of monitoring large numbers of sharks over spatial scales of 1 to $10 \mathrm{~s}$ of km (e.g. Australian Animal Tagging And Monitoring System: IMOS 2009). As a result, there has been a marked increase in the number of publications that have presented data from acoustic monitoring and satellite telemetry studies. Such studies have focused on quantifying the spatial and temporal variation in habitat use of coastal sharks (e.g. Yeiser et al. 2008). Despite the increasing numbers of dedicated studies, the relative newness of this field means that little information is available on movement patterns compared to other aspects of shark ecology such as diet composition and growth patterns. Furthermore, dedicated studies have been concentrated on a limited range of species in only a few areas globally (Fig. 1).

Inter-specific habitat use is also an under-developed area of study for coastal shark management despite its importance for identifying areas that serve different functions for different species. Communal nursery areas have been described (e.g. Castro 1993, Simpfendorfer \& Milward 1993, Yokota \& Lessa 2006), but we still have a poor understanding of how species partition nurseries from other phases. It is only recently that some researchers have started to address habitat use of multiple species of coastal sharks and considered multi-species management in these areas (White \& Potter 2004, Chapman et al. 2005, Pikitch et al. 2005, Wiley \& Simpfendorfer 2007, DeAngelis et al. 2008, Yeiser et al. 2008).

The lack of synthesis of shark movement, habitat use and partitioning data that exist impedes the development and progression of conservation and management. Here we present an up-to-date summary of outcomes from studies of coastal shark movement, as well as the associated implications for their management 


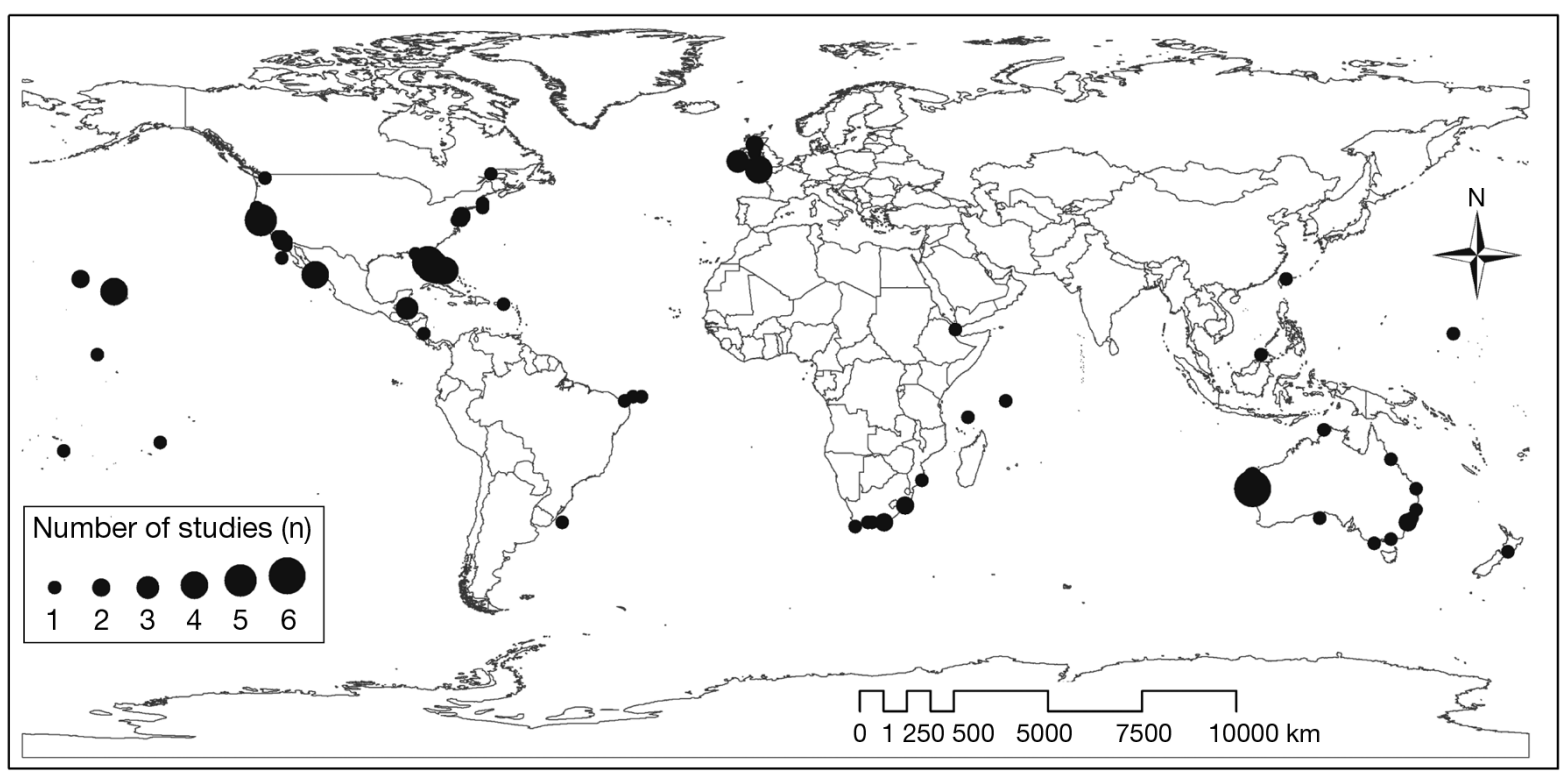

Fig. 1. Locations of shark movement studies within coastal environments ( $\mathrm{n}=106)$

and conservation. To avoid ambiguity, we define 'coastal resident sharks' as species that solely inhabit coastal waters (i.e. distributed out to the continental shelf), or spend the majority of their life in coastal habitats. Sharks that visit coastal areas but are typically referred to as 'oceanic' or 'pelagic', are defined as 'coastal transient sharks' and are included where studies were done while animals were in the coastal zone. We separate our review into 4 sections that focus on determinants of extinction risk in sharks: (1) range and dispersal, (2) habitat specificity, (3) segregation and habitat partitioning, and (4) conservation and management. Our review includes studies that have used direct observation, conventional fish tags for capturemark-recapture, acoustic tags and satellite tags.

\section{RANGE AND DISPERSAL}

For most taxa, small range size and restricted dispersal capacity increase extinction risk and reduce the recovery capacity of populations after exploitation (Brook et al. 2008). It is therefore intuitive that given equal rates of harvest, sharks with small range sizes will be more vulnerable to population decline than those that range widely (Field et al. 2009). As with any mobile marine organism, the range and dispersal capacity of sharks must be considered from both vertical and horizontal perspectives. More effort has been applied to studying horizontal than vertical patterns (Fig. 2), which is a reflection of technology and possibly the relatively shallow habitats used by many coastal sharks. Approximately $33 \%(n=34)$ of studies conducted thus far have included a vertical movement component, compared to approximately $91 \%(n=96)$ that have a horizontal component (Table S1 in the electronic supplement at www.int-res.com/articles/suppl/ m408p275_supp.pdf). In general, coastal transient sharks over $4 \mathrm{~m}$ total length (TL) (e.g. white sharks Carcharodon carcharias, basking sharks Cetorhinus maximus, whale sharks Rhincodon typus and tiger sharks Galeocerdo cuvier) (Fig. 2B) have received more dedicated study on vertical movement than sharks that are coastal residents.

\section{Horizontal movements}

Geographical range and dispersal affect extinction risk in many taxa (Bradshaw et al. 2008, Sodhi et al. 2008a,b), including sharks (Field et al. 2009). A number of common patterns such as home range fidelity, diel cycles, shifting and expanding ranges and migration have been observed.

\section{Home range}

Home range has been defined as the spatially and temporally distinct area within which sharks do their normal activities (Morrissey \& Gruber 1993b). Intuitively, there is a correlation between body size and home range (e.g. Morrissey \& Gruber 1993b), suggesting that larger animals need more space to provide enough resources to accommodate their greater energetic requirements and behavioural repertoire 

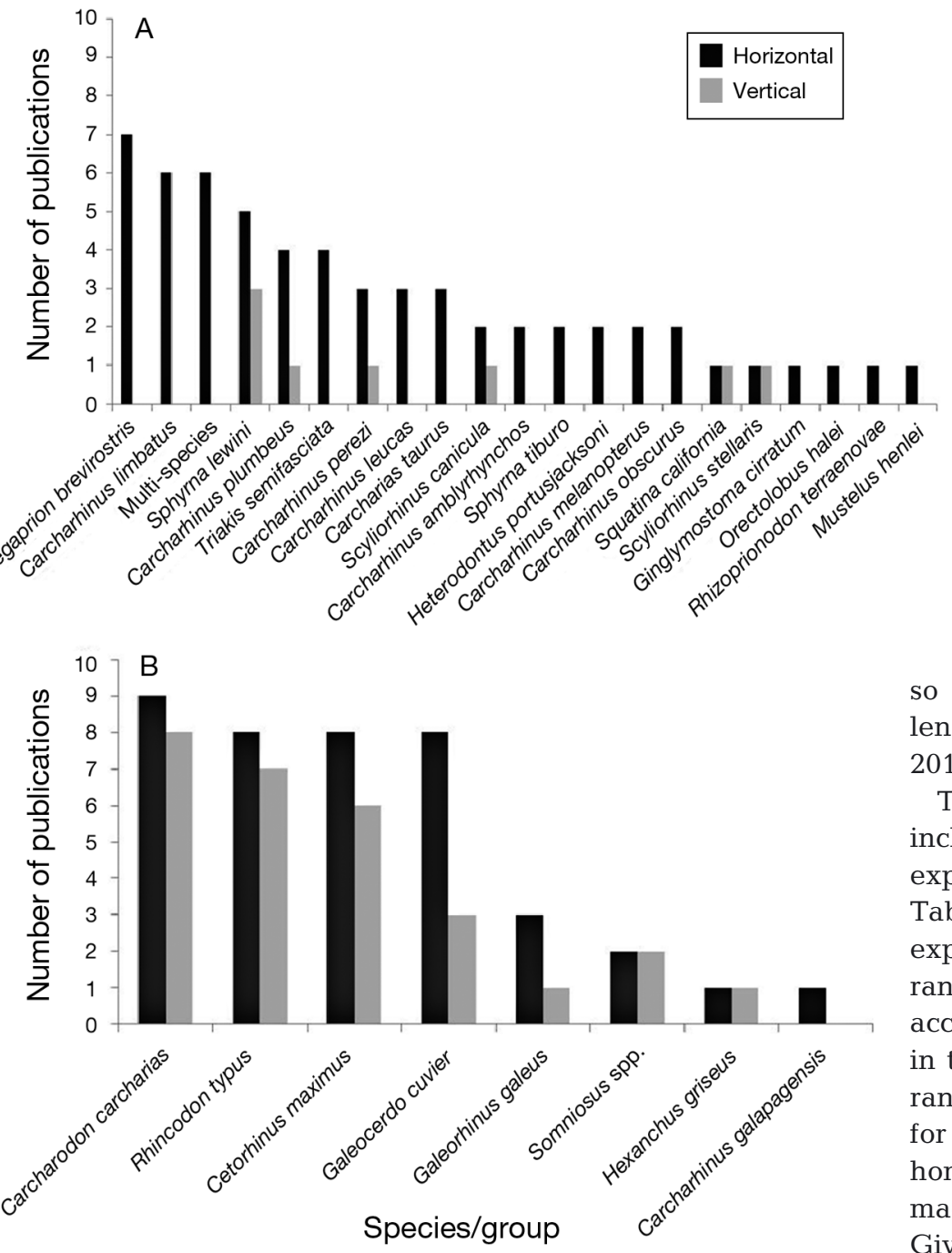

Fig. 2. Horizontal and vertical movement studies of sharks that are (A) coastal residents and (B) coastal transients

(McNab 1963). Most studies of home range in sharks are consistent with this idea, although there is considerable variability among species of equivalent body size. Furthermore, comparing home range sizes among studies is difficult due to differences in data collection methods, temporal scales, metrics used for home range calculation and the number and size class of individuals monitored.

We nonetheless collated home range data from 8 separate studies (McKibben \& Nelson 1986, Gruber et al. 1988, Holland et al. 1993, Morrissey \& Gruber 1993b, Goldman \& Anderson 1999, Rechisky \& Wetherbee 2003, Carlisle \& Starr 2009, Papastamatiou et al. 2009) for a total of 95 individuals from 7 species (Carcharhinus amblyrhynchos, Carcharhinus melanopterus, Carcharhinus plumbeus, Carcharodon carcharias, Negaprion brevirostris, Triakis semifasciata and Sphyrna lewini) to examine whether size influences estimates of home range. To account for the hypothesised effect of monitoring time and to control for non-independence of individuals within species, we constructed general linear mixed-effects models with $\log _{10}$ home range size $\left(\mathrm{km}^{2}\right)$ as the response. Fixed effects included the $\log _{10}$ of monitoring time (d) and the $\log _{10}$ of TL $(\mathrm{cm})$, and the random effect was set as 'species'. Only 3 models with a Gaussian error distribution and identity link were contrasted using Akaike's information criterion weights corrected for small samples ( $w_{\text {AIC }}$; Burnham \& Anderson 2002): $\sim$ time $+\mathrm{TL}, \sim$ time, and the intercept-only model (Table 1). Some studies only reported fork length or pre-caudal length, so these were converted to TL using lengthlength equations from FishBase (Froese \& Pauly 2010).

The top-ranked model $\left({ } \mathrm{AIC}_{c}=0.98\right)$ included both time and TL fixed effects and explained $22.6 \%$ of the total deviance (\%DE; Table 1). The second-ranked time-only model explained $16.5 \%$ of the deviance in $\log _{10}$ home range size (Table 1), demonstrating that TL accounts for approximately $6 \%$ of the deviance in the response. The TL coefficient in the topranked model was $1.38 \pm 0.43$, indicating that for every order of magnitude increase in TL, home range size increases by 1.38 orders of magnitude (demonstrated visually in Fig. 3). Given that our dataset only covered approximately 1 order of magnitude in shark size (minimum $\mathrm{TL}=51 \mathrm{~cm}$; maximum $=490 \mathrm{~cm}$ ) mainly among species, it is conceivable that a greater variation in sizes both within and among species would reveal a larger effect of TL on home range size (controlling for monitoring time).

Generally, coastal resident sharks up to $2.5 \mathrm{~m}$ TL appear to be limited to areas less than $100 \mathrm{~km}^{2}$. For

Table 1. Home range size (response) versus monitoring time (time) and total length (TL) general linear mixed-effects model comparison based on Akaike's information criterion corrected for small samples $\left(\mathrm{AIC}_{c}\right)$. All models include the random effect 'species'. LL: maximum log-likelihood, $k$ : number of parameters, AIC $_{c}$ : $\mathrm{AIC}_{c}$ weight, \%DE: \% deviance explained

\begin{tabular}{|lccccr|}
\hline Model & LL & $k$ & $\mathrm{AIC}_{c}$ & $w_{\mathrm{AIC}}$ & $\% \mathrm{DE}$ \\
\hline$\sim$ Time + TL & -65.173 & 5 & 141.027 & 0.9801 & 22.6 \\
$\sim$ Time & -70.187 & 4 & 148.823 & 0.0199 & 16.5 \\
$\sim 1$ (null) & -83.062 & 3 & 172.391 & 0.0000 & 0.0 \\
\hline
\end{tabular}


example, Morrissey \& Gruber (1993b) found that small (mean TL $=0.73 \mathrm{~m}$ ) juvenile lemon sharks Negaprion brevirostris had home ranges between 0.23 and $1.26 \mathrm{~km}^{2}$ (mean $\left.=0.68 \mathrm{~km}^{2}\right)$, while larger juveniles (1.68 to $2.30 \mathrm{~m}$ TL) ranged between 18 and $93 \mathrm{~km}^{2}$ (tracked for $6 \mathrm{~h}$ periods). Juvenile lemon (mean stretched TL $=207.8 \pm 7.1$ ) and bull sharks Carcharhinus leucas (mean stretched TL $=151 \pm 4.6 \mathrm{SE}$ ) had home ranges of up to $40 \mathrm{~km}^{2}$ (monitored over weeks; Yeiser et al. 2008). Apart from lemon sharks, other reef sharks have restricted home ranges, such as grey reef sharks C. amblyrhynchos (mean TL $=150.9 \pm 2.0 \mathrm{SE}$ ) with minimum home ranges of 0.19 to $53 \mathrm{~km}^{2}$ (mean size $=4.2 \mathrm{~km}^{2}$; intermittent multi-day tracks; McKibben \& Nelson 1986) and blacktip reef sharks $C$. melanopterus with home ranges of only a few square kilometres (tracked up to $7 \mathrm{~h}$; Stevens 1984) or less (0.55 $\pm 0.24 \mathrm{~km}^{2}$; intermittent diurnal day to week tracks; Papastamatiou et al. 2009). Bonnethead sharks Sphyrna tiburo (mean TL $=77.8 \pm 1.4$ ) also have small home ranges $\left(8.3 \mathrm{~km}^{2}\right)$; however, some individuals use larger areas (up to $74 \mathrm{~km}^{2}$; monitored 1 to $173 \mathrm{~d}$; Heupel et al. 2006b). Pacific angel sharks Squatina californica have limited home ranges $\left(\sim 1.5 \mathrm{~km}^{2}\right.$; tracked 13 to $25 \mathrm{~h}$; Standora \& Nelson 1977), as do male dogfish (4.3 to $5.4 \mathrm{~km}^{2}$; intermittent tracks between 5.6 and $6 \mathrm{~d}$; Sims et al. 2001). Mean minimum home ranges for female leopard sharks Triakis semifasciata are less than $1 \mathrm{~km}^{2}$ (tracked 20 to $71.5 \mathrm{~h}$; Carlisle \& Starr 2009), while the average home range size for juvenile sharpnose sharks Rhizoprionodon terraenovae is only $1.29 \mathrm{~km}^{2}$ (monitored 1 to $37 \mathrm{~d}$; Carlson et al. 2008).

As with the previous examples, many coastal sharks have limited home ranges; however, it is not uncommon for individuals to make much longer excursions that extend far beyond their usual home ranges (e.g. Stevens et al. 2000b). Lemon (Morrissey \& Gruber 1993b), juvenile blacktip Carcharhinus limbatus (Heupel et al. 2004) and grey reef sharks (McKibben \& Nelson 1986, Heupel et al. 2010) provide good examples. Heupel et al. (2004) suggested that longer movements in juvenile blacktip sharks might be related to foraging and/or atmospheric pressure declines associated with approaching storms (Heupel et al. 2003).

Coastal transient sharks often do not have specific home ranges, although tiger sharks in Western Australia appear to restrict their movements within large areas (>1000s of $\mathrm{km}^{2}$ ) over periods of days to weeks (Heithaus et al. 2007). Similarly, tiger sharks in Hawaii maintain large home ranges, which can include more than one island and offshore waters (tracked 7 to 50 h) (Holland et al. 1999). A study of white sharks at a northern elephant seal Mirounga angustirostris colony found minimum home range sizes between 1.84 and $9.15 \mathrm{~km}^{2}$ (diurnal tracks over days to weeks; Goldman \& Anderson 1999), although ranges outside of the coastal zone are many orders of magnitude larger due to seasonal migrations (e.g. Boustany et al. 2002, Bonfil et al. 2005, Bruce et al. 2006, Weng et al. 2007a, Domeier \& Nasby-Lucas 2008).

\section{Diel movement patterns}

Diel movement patterns recorded from tracking studies have generally found that sharks increase their activity and home range at night, which has been attributed to increased foraging activity. For example, McKibben \& Nelson (1986) found a 3-fold increase in the home range of grey reef sharks from day $\left(10.3 \mathrm{~km}^{2}\right)$

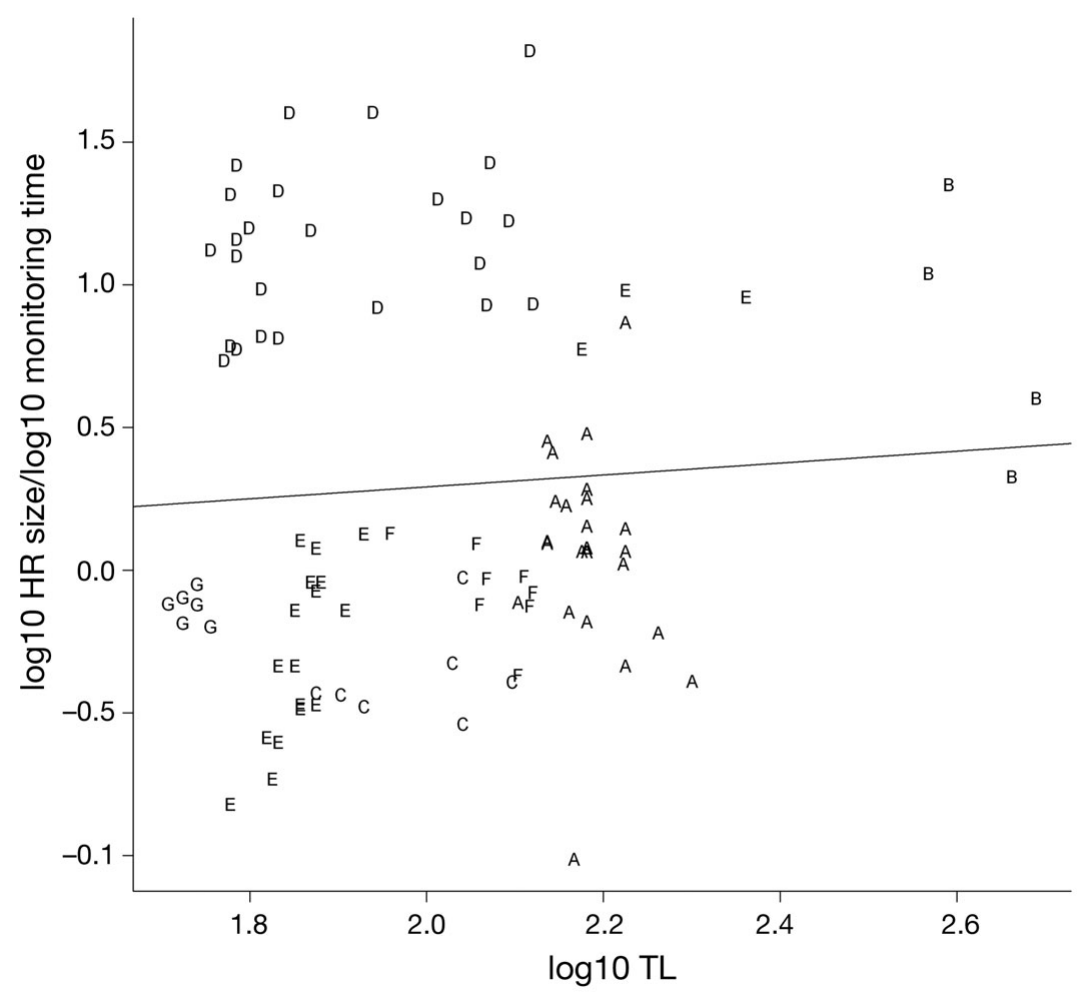

Fig. 3. Relationship between $\log _{10}$ home range size (HR) (corrected for $\log _{10}$ monitoring time) and $\log _{10}$ shark total body length (TL). See text (Range and Dispersal) for full details of analysis. Letters represent species (A: Carcharhinus amblyrhynchos, B: Carcharodon carcharias, C: Carcharhinus melanopterus, D: Carcharhinus plumbeus, E: Negaprion brevirostris, F: Triakis semifasciata, and G: Sphyrna lewini) 
to night $\left(28.5 \mathrm{~km}^{2}\right)$. Similarly, both juvenile and adult scalloped hammerhead sharks have smaller daytime core areas and range more widely at night (Klimley \& Nelson 1984, Holland et al. 1992, 1993). Juvenile Caribbean reef sharks increase movement at night (Garla et al. 2006), as do male dogfish (Sims et al. 2001), sixgill sharks Hexanchus griseus (Andrews et al. 2009), leopard sharks (Ackerman et al. 2000, Hight \& Lowe 2007), white tip reef sharks Triaenodon obesus (Whitney et al. 2007), grey reef sharks (McKibben \& Nelson 1986), lemon sharks (Gruber et al. 1988) and Pacific angel sharks (Standora \& Nelson 1977). In contrast, bonnethead sharks show no consistent diel patterns in home range size (Heupel et al. 2006b), nor do juvenile and neonate sandbar sharks Carcharhinus plumbeus show any diel pattern in movement rate (Rechisky \& Wetherbee 2003).

\section{Shifting and expanding ranges}

Shifting and expanding ranges and other broadscale patterns associated with tides and migrations can only be observed through long-term studies (Nelson 1990), which are now possible with acoustic monitoring and satellite tracking. It is likely that an ontogenetic shift in home range size accompanies bioenergetic functions (e.g. Heupel et al. 2004, Field et al. 2005) that take into account the reduced threat of predation with increasing body size, shifting diets through time, and the onset of reproduction. The pattern of expanding ranges with increasing body size was described for school sharks in an early study by Olsen (1954) where sharks $(<0.70 \mathrm{~m} \mathrm{TL})$ moved more as they grew. Similar patterns have been observed for grey nurse (ragged tooth) sharks Carcharias tauras (Dicken et al. 2007) and large juvenile white sharks, which range more widely than young-of-the-year in coastal adult habitats likely as a consequence of changing physiology (Weng et al. 2007b) or resource exclusion. Lemon sharks also undergo an ontogenetic expansion of home ranges, with juveniles showing strong site fidelity and movement between tidal refuges, while adults range farther (Gruber et al. 1988, Morrissey \& Gruber 1993b, Wetherbee et al. 2007, Chapman et al. 2009). Similarly, juvenile blacktip sharks expand their home range over months due to changes in environmental conditions or ontogenetic changes in behaviour (Heupel \& Hueter 2001, Heupel et al. 2004, Heupel \& Simpfendorfer 2005a). This also occurs in juvenile sandbar sharks (Merson \& Pratt 2001), but home range size does not differ between juveniles and neonates (Rechisky \& Wetherbee 2003). Juvenile Caribbean reef sharks also expand their range as they grow and explore deeper sites (Chapman et al. 2005, Garla et al.
2006). In contrast, Duncan \& Holland (2006) reported no shift in habitat use by juvenile scalloped hammerhead sharks in their nursery area, nor did Heupel et al. (2006b) find any change of home range size among bonnethead sharks over time, although the location changed possibly because of shifting prey distribution and abundance. Although range expansion with increasing size might merely reflect greater opportunity for sharks to disperse with increasing time at liberty between capture events (e.g. school sharks, Hurst et al. 1999), there is little evidence for this in other species (e.g. Stevens et al. 2000b, Heupel et al. 2006b).

Interestingly, coastal transient sharks over $4 \mathrm{~m} \mathrm{TL}$ have shown opposing movement patterns among size classes. For example, an inverse relationship between $\mathrm{TL}$ and range size exists for white sharks feeding at a seal colony, possibly due to the differing diets or hunting inexperience of smaller individuals (Goldman \& Anderson 1999). Similarly, larger sixgill sharks made shorter daily movements than smaller individuals in a study conducted in Puget Sound (Andrews et al. 2007). Juvenile tiger sharks are also wider-ranging and spend less time in localised areas than adults, which might be due to predation risk on juveniles from adults or possibly resource exclusion (Meyer et al. 2009) .

\section{Migrations}

Migrations are common in most species of sharks (Bres 1993) and range from short, seasonal movements along coasts (e.g. Bruce et al. 2006) to transoceanic (e.g. Eckert \& Stewart 2001, Eckert et al. 2002, Gore et al. 2008) and trans-equatorial (e.g. Skomal et al. 2009) crossings. Migrations are often related to reproductive behaviour, seasonal shifts in prey distribution and abundance, or to thermal tolerances associated with changing water temperatures (Springer 1967). Both coastal and transoceanic migrations occur in coastal transient species such as white sharks (Bonfil et al. 2005). Transoceanic migrations are possibly a result of changing reproductive status, whereas coastal migration, particularly in juveniles, might arise in response to shifting prey distribution (Bonfil et al. 2005). Indeed, shorter seasonal migrations of white sharks in Australia along the east coast during autumn-winter are possibly related to prey movements (Bruce et al. 2006), and in some cases distinct 'migratory corridors' have been identified from tracked individuals (Bruce et al. 2006, Weng et al. 2007a). Similarly, coastal migrations of basking sharks have been along the continental shelf to areas of high prey availability (Sims et al. 2003) and steep gradients in sea surface temperature (Skomal et al. 2004, Sims 2008). 
Sharks less than $4 \mathrm{~m}$ TL also migrate within the coastal zone over broad spatial scales. For example, female grey nurse sharks make biennial reproductive migrations along the eastern coastline of southern Africa (Dicken et al. 2006, 2007). Dusky sharks Carcharhinus obscurus also migrate along the coast of South Africa following changes in water temperature and the migration of their prey sardine Sardinops sagax (Hussey et al. 2009). Sandbar sharks are also highly migratory (Kohler \& Turner 1998), with adults migrating annually along the eastern coast of North America from overwintering areas in the Gulf of Mexico to summer nurseries such as Delaware Bay (Merson \& Pratt 2001, Rechisky \& Wetherbee 2003). Similarly, both adult and juvenile blacktip sharks migrate seasonally along the coast of the USA, departing Florida when water temperature falls below $21^{\circ} \mathrm{C}$ (Hueter \& Manire 1994, Heupel \& Hueter 2001). A long-term tagging study in the Northern Territory of Australia also found recaptures of spot tail Carcharhinus sorrah and Australian blacktip Carcharhinus tilstoni to have moved more than $1000 \mathrm{~km}$ from their tagging locations, movements generally being along the coast (Stevens et al. 2000b). Bull sharks have been found to traverse the length of riverine systems, such as the Rio San Juan (Thorson 1971). Even demersal sharks such as Port Jackson sharks Heterodontus portusjacksoni move up to $760 \mathrm{~km}$ offshore and southwards from their oviposition sites to their foraging refuges, coinciding with changing water temperature (McLaughlin \& O'Gower 1971, O'Gower 1995).

\section{Vertical movements}

The depths at which sharks are distributed and move among differ with life stage, sex, time of day or season, and they can affect susceptibility to harvest (e.g. West \& Stevens 2001). Similar to horizontal movement patterns, several common patterns in vertical movement exist such as oscillatory vertical displacement, surface swimming, swimming at depth, diel vertical migration and ontogenetic shifts. Most studies quantifying vertical movements have tended to focus on coastal transient species.

\section{Oscillatory vertical displacement}

Oscillatory vertical displacement ('yo-yo diving') is a pattern of regular movement between the surface or near-surface and deeper waters. This behaviour has mainly been recorded in coastal transient sharks such as whale sharks, which regularly 'dive' to and from the near-surface and deeper waters (Gunn et al. 1999,
Brunnschweiler et al. 2009), basking sharks, which move to and from the bottom of shelf and shelf-edge habitats (Sims et al. 2003, 2005a, Shepard et al. 2006), and white sharks (Strong et al. 1996, Klimley et al. 2002, Bruce et al. 2006, Weng et al. 2007a, Domeier \& Nasby-Lucas 2008). Deep-water species that visit coastal areas such as Pacific sleeper sharks Somniosus pacificus and Greenland sharks $S$. microcephalus have also displayed similar patterns (Stokesbury et al. 2005, Hulbert et al. 2006). This behaviour has also been observed in coastal resident sharks such as the scalloped hammerhead shark (Klimley 1993, Jorgensen et al. 2009). For most species, this behaviour has been attributed to foraging, with the exception of scalloped hammerheads, which could be using such vertical movements to navigate via differences in intensity of localised magnetic gradients during migration (Klimley 1993). Other possible explanations for the existence of this behaviour are for thermoregulation and energy conservation (Klimley et al. 2002, Wilson et al. 2006).

\section{Surface swimming}

Surface swimming for prolonged periods (hours to days or weeks) is seen in certain coastal transient species, even where 'diving' behaviour is theoretically possible. This behaviour has been observed in whale (Wilson et al. 2006), white (Klimley et al. 2002, Bonfil et al. 2005, Bruce et al. 2006), tiger (Tricas 1981, Holland et al. 1999), and school sharks Galeorhinus galeus (West \& Stevens 2001). Explanations for surface swimming include using the Earth's dipole field and/or celestial signs to navigate, thermoregulate (Klimley et al. 2002) and feed on schools of prey at the surface by whale sharks (Colman 1997, Jarman \& Wilson 2004, Graham \& Roberts 2007).

\section{Swimming at depth}

Swimming at depth is the pattern of making a vertical displacement away from surface waters and then remaining at depth for prolonged periods. White sharks spent little time in mid-water when at shallow depths around one feeding site (e.g. Strong et al. 1996); however, they spent the majority of their time $(60 \%$ in daytime, $90 \%$ at night) in the mixed layer (average of $60 \mathrm{~m}$ ) when at another feeding site (e.g. Domeier \& Nasby-Lucas 2008). The mixed layer appears to be an important foraging habitat, particularly for juvenile white and whale sharks (Gunn et al. 1999, Weng et al. 2007b). Other patterns of swimming at depth have been recorded for a number of species, such as bottomoriented swimming in shallow water $(<30 \mathrm{~m})$ in white 
(Goldman \& Anderson 1999) and tiger sharks (Tricas 1981, Holland et al. 1999), as a foraging strategy to remain cryptic to prey (Goldman \& Anderson 1999), and temporal differences in vertical displacement in large juvenile sandbar sharks that dive deeper in winter ( 0 to $72 \mathrm{~m}$ ) than in summer (0 to $24 \mathrm{~m}$ ) during their coastal migration along the eastern coast of North America (Conrath \& Musick 2008).

\section{Diel vertical migration}

Diel vertical migration is the vertical movement of organisms from deeper waters during the day to nearsurface at night following the movement of plankton that are attempting to avoid visual predation (Bollens \& Frost 1989). Vertical movements of planktivorous sharks such as whale and basking sharks have shown such patterns (Graham et al. 2006, Wilson et al. 2006); however, reverse diel vertical migration (nocturnal movement to deeper waters) has also been observed in the same species (Sims et al. 2005a, Shepard et al. 2006, Rowat et al. 2007). Migration in school sharks in coastal waters suggests a lunar effect on vertical migration patterns (West \& Stevens 2001), similar to juvenile white sharks, which make deeper dives during full moons, possibly to follow prey that have lightmediated vertical migration (Weng et al. 2007b). Deepwater species such as sixgill, Greenland and Pacific sleeper sharks are more active at night and occupy shallower depths than during the day when in coastal areas, which is also likely linked to foraging (Stokesbury et al. 2005, Hulbert et al. 2006, Andrews et al. 2009). This behaviour has also been observed in one coastal resident species, the dogfish Scyliorhinus canicula. Males of this species make such migrations when they are more active at night in warm, prey-rich surface waters (Sims et al. 2006), whereas females move deeper during crepuscular and nocturnal periods for reproduction and foraging (Sims et al. 2001). Although not considered a complete diel vertical migration, Caribbean reef sharks increase the amount of time they spend near the surface $(<40 \mathrm{~m})$ at night (Chapman et al. 2007).

\section{Ontogenetic shifts}

Ontogenetic shifts in vertical movement patterns have been described for a few coastal transient species, although they are less common than other vertical movements described above. Differences in depth distribution within species (e.g. Wetherbee et al. 1996, Pikitch et al. 2005, McAuley et al. 2007, Andrews et al. 2009) can arise from intra-specific predator avoidance and resource exclusion, or they are a reflection of ontogenetic shifts in diet and physiological development. A study of adult and juvenile basking sharks tracked along the continental shelf west of the United Kingdom showed potential ontogenetic differences in vertical movement patterns, with one tagged juvenile spending longer periods at constant depths, weaker magnitudes of diving patterns, slower ascent and descent rates and an absence of strong diel movements than were generally observed in adults (Shepard et al. 2006). Such patterns possibly reflect a lack of foraging experience in juveniles compared to adults (Sims et al. 2008). Variation in vertical displacement has also been observed among size classes of juvenile white sharks in a nursery area in the eastern Pacific, with larger juveniles (3-yr olds) making deeper vertical excursions than young-of-the-year (Weng et al. 2007b). This could arise because of a greater thermal tolerance of larger individuals relative to young-of-the-year, allowing the former to withstand cooler temperatures to expand their foraging niche.

\section{HABITAT SPECIFICITY}

Habitat specificity is defined as the degree to which a species occurs in a number of different habitats or is restricted to one or a few sites (Rabinowitz et al. 1986). This behaviour often occurs due to physical and biotic requirements of animals, which in turn determine habitat selection. Therefore, to understand how fishes distribute themselves, quantifying which habitats they choose, when they choose them and why needs addressing (Sims 2003). The potential importance of physical and biotic factors in habitat selection by sharks has been reviewed by Simpfendorfer \& Heupel (2004) and has been addressed by approximately $75 \%$ ( $\mathrm{n}=79$ ) of the studies included in our review (Table S1 in the supplement). Influences such as tide, water temperature, salinity, dissolved oxygen, substratum type and depth affect the distribution of coastal elasmobranchs, with greater responses for some species and size classes (Economakis \& Lobel 1998, Ackerman et al. 2000, Hopkins \& Cech 2003, Simpfendorfer et al. 2005, DeAngelis et al. 2008, Vogler et al. 2008, Campos et al. 2009, Heithaus et al. 2009b, Ubeda et al. 2009). To date, depth and temperature have been measured with shark movement for many species, followed by tide, current, benthos type, salinity, prey and dissolved oxygen associations (Table 2).

Morrissey \& Gruber (1993a) found that juvenile lemon sharks selected shallow waters where temperatures were above $30^{\circ} \mathrm{C}$, which served to maintain optimal metabolic performance while avoiding predators. A study of bat rays Myliobatus californica, leopard 
Table 2. Environmental variables monitored in relation to movement and habitat specificity of coastal sharks. Checkmarks indicate that the category was monitored in at least one study for the species; $\boldsymbol{x}$ indicates that the category was not monitored. R: coastal resident; T: coastal transient; Total: number of species where corresponding environmental variable was monitored with movement

\begin{tabular}{|c|c|c|c|c|c|c|c|c|}
\hline Species & Class & Benthos type & Tide or current & Temperature & Depth & Salinity & Dissolved $\mathrm{O}_{2}$ & Prey \\
\hline Carcharhinus amblyrhynchos & $\mathrm{R}$ & $x$ & $x$ & $\checkmark$ & $\checkmark$ & $x$ & $x$ & $x$ \\
\hline Carcharhinus leucas & $\mathrm{R}$ & $x$ & 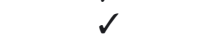 & $\checkmark$ & $x$ & $s$ & $\checkmark$ & $x$ \\
\hline Carcharhinus limbatus & $\mathrm{R}$ & 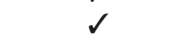 & $\checkmark$ & $\checkmark$ & $s$ & $\checkmark$ & $x$ & 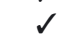 \\
\hline Carcharhinus melanopterus & $\mathrm{R}$ & $\checkmark$ & $\checkmark$ & $x$ & $x$ & $x$ & $x$ & $x$ \\
\hline Carcharhinus perezi & $\mathrm{R}$ & $\checkmark$ & $x$ & $x$ & $\checkmark$ & $x$ & $x$ & $x$ \\
\hline Carcharhinus plumbeus & $\mathrm{R}$ & $x$ & $\checkmark$ & $\checkmark$ & $\checkmark$ & $\checkmark$ & $x$ & $x$ \\
\hline Carcharodon carcharias & $\mathrm{T}$ & $x$ & $x$ & $\checkmark$ & $\checkmark$ & $x$ & $x$ & $x$ \\
\hline Cetorhinus maximus & $\mathrm{T}$ & $x$ & $\checkmark$ & $\checkmark$ & $\checkmark$ & $x$ & $x$ & $\checkmark$ \\
\hline Galeocerdo cuvier & $\mathrm{T}$ & $s$ & $x$ & $\checkmark$ & $s$ & $x$ & $x$ & 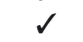 \\
\hline Galeorhinus galeus & $\mathrm{T}$ & $x$ & $x$ & $x$ & $s$ & $x$ & $x$ & $x$ \\
\hline Ginglymostoma cirratum & $\mathrm{R}$ & $\checkmark$ & $x$ & $x$ & $x$ & $x$ & $x$ & $x$ \\
\hline Hexanchus griseus & $\mathrm{T}$ & $x$ & $d$ & $d$ & $d$ & $x$ & $x$ & $x$ \\
\hline Mustelus henlei & $\mathrm{R}$ & $x$ & $\checkmark$ & $x$ & $x$ & $x$ & $x$ & $x$ \\
\hline Negaprion brevirostris & $\mathrm{R}$ & $\checkmark$ & $\checkmark$ & $s$ & $s$ & $s$ & $x$ & $\checkmark$ \\
\hline Orectolobus ornatus & $\mathrm{R}$ & $\checkmark$ & $x$ & $x$ & $x$ & $x$ & $x$ & $\checkmark$ \\
\hline Rhincodon typus & $\mathrm{T}$ & $x$ & 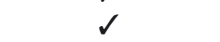 & 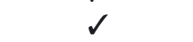 & 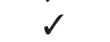 & $s$ & $x$ & 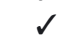 \\
\hline Rhizoprionodon terraenovae & $\mathrm{R}$ & $s$ & $x$ & $x$ & $s$ & $x$ & $x$ & $x$ \\
\hline Scyliorhinus canicula & $\mathrm{R}$ & $x$ & $x$ & $\checkmark$ & $\checkmark$ & $x$ & $x$ & $\checkmark$ \\
\hline Somniosus microcephalus & $\mathrm{T}$ & $x$ & $x$ & $\checkmark$ & $\checkmark$ & $x$ & $x$ & $x$ \\
\hline Somniosus pacificus & $\mathrm{T}$ & $x$ & $x$ & $\checkmark$ & $\checkmark$ & $x$ & $x$ & $x$ \\
\hline Sphyrna lewini & $\mathrm{R}$ & $x$ & $\checkmark$ & $\checkmark$ & $x$ & $x$ & $\checkmark$ & $x$ \\
\hline Sphyrna tiburo & $\mathrm{R}$ & $\checkmark$ & $\checkmark$ & $x$ & $x$ & $\checkmark$ & $x$ & $x$ \\
\hline Squatina californica & $\mathrm{R}$ & $x$ & $x$ & $\checkmark$ & $\checkmark$ & $x$ & $x$ & $x$ \\
\hline Squatina guggenheim & $\mathrm{R}$ & $x$ & $x$ & $\checkmark$ & $\checkmark$ & $s$ & $x$ & $x$ \\
\hline Triakis semifasciata & $\mathrm{R}$ & $x$ & $s$ & $\checkmark$ & $s$ & $\checkmark$ & $\checkmark$ & $x$ \\
\hline Multi-species & $\mathrm{R}$ & $\checkmark$ & $\checkmark$ & $\checkmark$ & $\checkmark$ & $\checkmark$ & $x$ & $\checkmark$ \\
\hline Total & & 10 & 13 & 18 & 19 & 9 & 3 & 8 \\
\hline
\end{tabular}

sharks and smooth hound sharks Mustelis henlei in California found that the movements and distributions were also affected by temperature, as well as salinity (Hopkins \& Cech 2003). Salinity might also affect the movement and distribution of bonnethead (Ubeda et al. 2009) and bull sharks in a Florida estuary, although temperature (Simpfendorfer et al. 2005, Heupel \& Simpfendorfer 2008), water flow (Heupel \& Simpfendorfer 2008, McCord \& Lamberth 2009) and dissolved oxygen also appear to be important (Heithaus et al. 2009a). Dissolved oxygen might also affect movements of female leopard sharks (Carlisle \& Starr 2009). Because water measurements such as salinity, water temperature and dissolved oxygen are inter-correlated (Heupel \& Simpfendorfer 2008), determining the main drivers of movement and distribution has proven difficult in some instances.

Short-term movements of juvenile sandbar sharks are positively correlated with current speed and direction (Medved \& Marshall 1983), as are the movements of leopard sharks in Tomales Bay, California, which likely arise as the predators follow prey moving with rising tides (Ackerman et al. 2000). Tide had the greatest effect on movement studies of smoothhound (Cam- pos et al. 2009) and female leopard sharks (Carlisle \& Starr 2009). The movement of whale sharks is also influenced by geostrophic currents (Rowat \& Gore 2007), in contrast to scalloped hammerhead sharks whose swimming is unaffected by current direction (Klimley \& Nelson 1984).

Sims (2003) noted that one of the main factors determining animal distribution patterns and therefore, habitat selection, is the relative abundance and availability of suitable prey. This idea is supported by evidence from sharks at opposing trophic levels such as tiger (Heithaus et al. 2002, Wirsing et al. 2007) and basking sharks (Sims \& Quayle 1998). The first satellite tracking of a basking shark (Priede 1984), and indeed any fish, has been re-analysed (Priede \& Miller 2009) and has revealed that the shark oriented itself with a thermal front in warm coastal waters, which potentially facilitated the tracking of prey. This has also been suggested as a possible explanation for juvenile whale sharks associating with thermal fronts (Hsu et al. 2007). Dicken et al. (2006) hypothesised that prey density is related to habitat choice for grey nurse sharks, whereby adults appear to follow the movement of the sardine run along the east coast of South Africa. In contrast, 
Heupel \& Hueter (2002) found no correlation between prey density and juvenile blacktip shark presence within a nursery, so they suggested instead that movement was affected by temperature and predator avoidance, as appears to be the case in juvenile lemon sharks (Morrissey \& Gruber (1993a). Similarly, movement patterns of lesser spotted dogfish, ornate wobbegong Orectolobus ornatus and juvenile bull sharks are not correlated with prey abundance (Carraro \& Gladstone 2006, Sims et al. 2006, Heithaus et al. 2009a).

\section{Site fidelity}

Correlations between the presence of sharks within a habitat and environmental conditions or in some cases, prey availability, might partially explain the repeated use of particular areas throughout a shark's life ('site fidelity'). The definition of site fidelity varies among studies, and the term is sometimes used synonymously with philopatry. Generally, all definitions of site fidelity refer to the repeated use of an area over time, for example 'area site fidelity' (Goldman \& Anderson 1999); 'daily site fidelity' (Chapman et al. 2005); 'long-term site fidelity' (Huveneers et al. 2006, Lowe et al. 2006, DeAngelis et al. 2008); 'seasonal site fidelity' (Dicken et al. 2007); 'site attachment' (Gruber et al. 1988, Wetherbee et al. 2007, Yeiser et al. 2008); and 'natal site-fidelity' (Chapman et al. 2009).
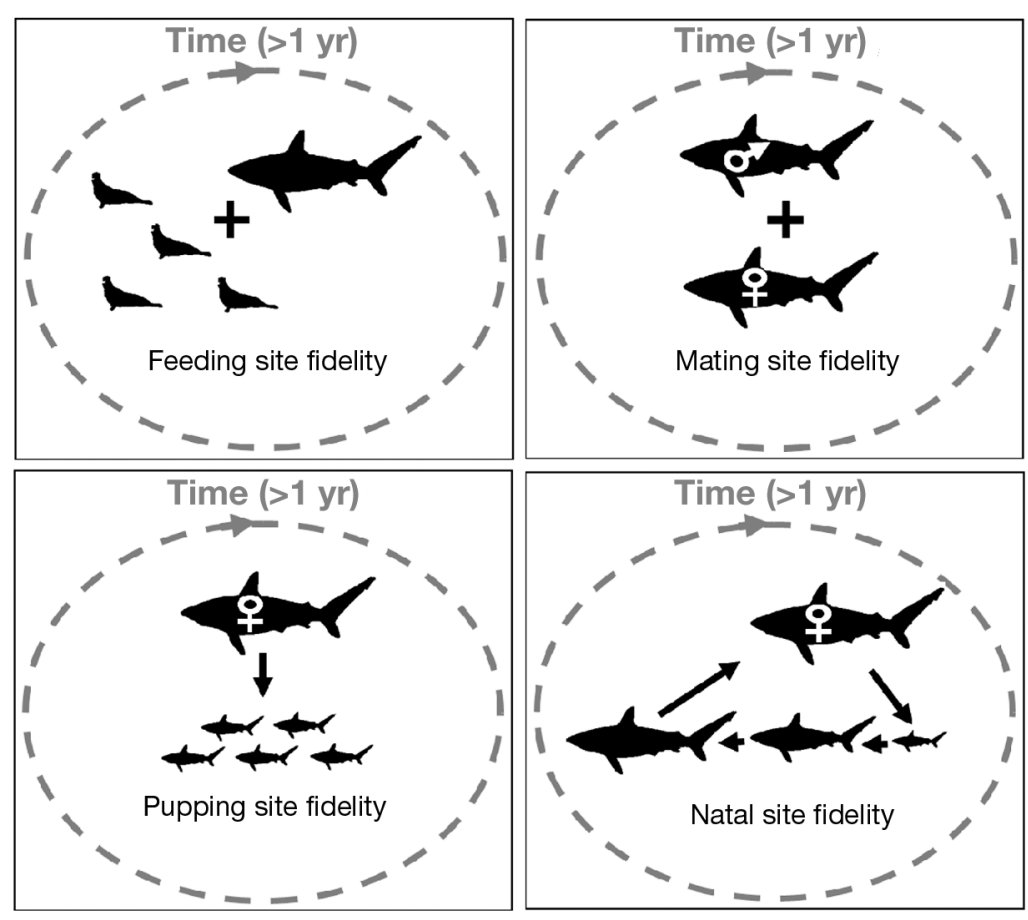

Fig. 4. Types of site fidelity observed in coastal sharks. (Grey line denotes visits to the same location over periods greater than $1 \mathrm{yr}$ )
The term 'philopatry' has been used less frequently, often within the context of long-term (over many years) use of an area by animals (e.g. Sims et al. 2001, 2005b, 2006, Hueter et al. 2004, Carlson et al. 2008, Domeier \& Nasby-Lucas 2008, Carlisle \& Starr 2009), or the longterm use of an area for reproduction (Sundström et al. 2001, Duncan \& Holland 2006) or feeding (Domeier \& Nasby-Lucas 2008). The term 'natal philopatry' (Hueter et al. 2004) has also been used synonymously with 'natal site-fidelity' (e.g. Chapman et al. 2009) to describe the repeated and long-term use of an area where an individual was born.

Given that tagging and tracking technology has developed to a point where 'long-term' (i.e. multiseason or multi-year) studies are now beginning to emerge, we suggest that the definition of this concept should now include qualifiers where information is available. As such, 'site fidelity' should be used to define the 'repeated use of an area, or multiple areas, over time', while the propensity to return to an area repeatedly to mate, which is common for some sharks, we define as 'mating site fidelity'. Following this logic, the repeated use of a natal area should be 'natal site fidelity', and the use of an area for pupping or feeding should thus be termed 'pupping site fidelity' and 'feeding site fidelity', respectively (Fig. 4).

Site fidelity is common in many sharks, especially in the use of nursery areas, reproduction or feeding areas. Juvenile hammerheads showed site fidelity to a nursery in Kane-ohe Bay, Hawaii, repeatedly returning for periods of up to 12 d during tracking (Holland et al. 1993). Surprisingly, adults continued to use this nursery despite it being highly degraded (Duncan \& Holland 2006). Site fidelity is also common in juvenile blacktip and lemon sharks in the Virgin Islands (DeAngelis et al. 2008), juvenile and adult lemon sharks at Bimini Islands (Gruber et al. 1988, Edren \& Gruber 2005, Chapman et al. 2009), juvenile and adult blacktip reef sharks at Palmyra Atoll (Papastamatiou et al. 2009), juvenile and to a lesser extent adult grey reef sharks on the Great Barrier Reef and in the Coral Sea, Australia (Heupel et al. 2010), juvenile Caribbean reef sharks in Fernando de Noronha Archipelago, Brazil (Garla et al. 2006), and large juvenile and adult Caribbean reef and nurse sharks at Glover's Reef Atoll (Chapman et al. 2005). Interestingly, juvenile lemon sharks (mean TL $1.35 \mathrm{~m}$ ) around Bimini demonstrate natal site fidelity by remaining near 
their natal area for periods of years after they have left their nursery (Chapman et al. 2009). There is also evidence of natal site fidelity in juvenile blacktip sharks (Hueter et al. 2004), and suggestions of its existence in sandbar sharks, both of which return to their pupping areas during years after parturition (Merson \& Pratt 2001). This behaviour has also been proposed for juvenile grey nurse sharks that were recaptured 1, 2 and 3 yr later near original capture sites (Dicken et al. 2007). Returning to a broad natal area after annual migrations has also been reported for Port Jackson sharks (McLaughlin \& O'Gower 1971).

Adult male and female nurse sharks display mating site fidelity by returning to the same site annually and every second year, respectively (Pratt \& Carrier 2001). Gestating female grey nurse sharks also aggregated at a specific site on the east coast of Australia and spent 78 to $90 \%$ of their time near the site over a $15 \mathrm{~d}$ period (Bansemer \& Bennett 2009). Coastal transient sharks over $4 \mathrm{~m}$ TL such as white and tiger sharks have also shown site fidelity to some coastal areas. White sharks (>4 m TL) have shown feeding site fidelity to northern elephant seal colonies at the South Farallon Islands, California, over more than 7 seasons, but smaller individuals have not (Goldman \& Anderson 1999). Similar behaviour has been observed for white sharks aggregating around Guadalupe Island to feed on Guadalupe fur seals Arctocephalus townsendi (Domeier \& NasbyLucas 2008). The absence of small juveniles could arise from ontogenetic differences in feeding or resource exclusion. Site fidelity and temporary residency have also been shown by white sharks in other coastal areas (Bruce et al. 2006, Johnson et al. 2009). Tiger sharks show some potential feeding site fidelity to the French Frigate Shoals, Hawaii, where 9 of 13 tagged sharks repeatedly visited particular islands over $3 \mathrm{yr}$ in response to concentrations of prey items (Lowe et al. 2006).

Other types of general site fidelity have been observed in several coastal resident species. Adult scalloped hammerhead sharks schooling around a seamount in the Gulf of California during the day return repeatedly after nocturnal excursions (Klimley \& Nelson 1984, Klimley et al. 1988). Adult female leopard sharks have also demonstrated diurnal site fidelity to coastal embayments, as well as some degree of longer site fidelity over the period of 1 yr (Hight \& Lowe 2007). Male dogfish have been recaptured and identified using numbered and acoustic tags over days and years (Sims et al. 2001, 2006). Similarly, nurse hounds Schliorhinus stellaris repeatedly use the same area for months (Sims et al. 2005b). Studies of other demersal sharks such as wobbegong sharks Orectolobus halei showed that they were faithful to small areas $\left(<200 \mathrm{~m}^{2}\right)$ monitored over several years (Huveneers et al. 2006). A sympatric species, the ornate wobbegong, used sites within a 75 ha area repeatedly for up to $211 \mathrm{~d}$ (Carraro \& Gladstone 2006), although no permanent residents were recorded.

\section{SEGREGATION AND HABITAT PARTITIONING}

The ontogenetic or species segregation of individuals is common in sharks (Springer 1967), particularly in coastal carcharhinids (Castro 1993), and could have evolved as a consequence of competition for resources or predation (Sims 2003). Such behaviour can also be a reflection of differing physiological tolerances to environmental conditions (see 'Habitat specificity' above). Other factors that influence segregation include sex, depth, benthic cover and water parameters (i.e. salinity, dissolved oxygen and temperature). Juveniles are at greater risk of predation than adults due to their smaller size (Herrel \& Gibb 2006), as are species less than $2.5 \mathrm{~m}$ TL. However, the prevalence and function of segregation and partitioning as a means of predator avoidance in sharks is still poorly understood, with only around $27 \%(\mathrm{n}=29)$ of publications included in our review addressing this topic (Table S1). The lack of good data describing such segregation impedes management and conservation because failure to protect the most important life stages contributing to population recovery and growth cannot be easily identified (Cailliet 1992, Bonfil 1997, Cortes 1999b, Field et al. 2009, Kinney \& Simpfendorfer 2009). Furthermore, knowledge of habitat partitioning by multiple species can be used to influence reserve design algorithms to take into account species complexes rather than single taxa (e.g. Watts et al. 2009).

Most of our current knowledge of habitat partitioning is based on studies of juvenile and immature life stages within nursery areas. In fact, approximately $67 \%(n=72)$ of studies included in our review examined juveniles, as opposed to approximately 56\% ( $\mathrm{n}=$ 59) that included adults (Table S1). According to Heupel et al. (2007), an area can only be classified as a nursery if it meets 3 criteria: (1) sharks ( $<1$ yr old) are more common in the area than other areas, (2) they remain in or return to the area for long periods, and (3) they use the area across years. Many coastal resident sharks use nursery habitats (e.g. lemon, sandbar, blacktip and scalloped hammerhead sharks), although few other species have been studied in detail. Reduction of predation risk by adults and a more reliable food supply have been postulated as the main reasons for the existence of nurseries (Springer 1967, Branstetter 1990, Castro 1993, Simpfendorfer \& Milward 1993). However, lack of correlation with prey abundance (Heupel \& Hueter 2002) and high juvenile mortality 
due to starvation (Duncan \& Holland 2006) do not support the latter hypothesis. Nursery areas might also provide added protection from predation due to poor visibility or limited accessibility by larger sharks. For example, juvenile hammerheads use deeper water with high mud and silt content during the day (Holland et al. 1993, Duncan \& Holland 2006). Other abiotic conditions might provide gradients to separate juvenile and adult habitats such as salinity (Simpfendorfer et al. 2005), temperature (McAuley et al. 2007), physical structures (Morrissey \& Gruber 1993a, McAuley et al. 2007), benthic cover (Carraro \& Gladstone 2006, Heithaus et al. 2006) and depth (Pikitch et al. 2005, Conrath \& Musick 2008).

The smallest size classes of bull sharks live within the fresher water of rivers and likely disperse to estuarine habitats once achieving more than $0.95 \mathrm{~m}$ TL (Simpfendorfer et al. 2005). Immature sharks favour lower salinities, which suggest that a change in physiological tolerances with age contributes to niche separation (Simpfendorfer et al. 2005, Wiley \& Simpfendorfer 2007, Heupel \& Simpfendorfer 2008). Yeiser et al. (2008) also observed that both juvenile bull and lemon sharks make use of estuarine areas and move in different patterns compared to adults. While tolerating higher salinities has large energetic costs for juveniles, it could provide an effective refuge against predation by larger individuals.

Juvenile sandbar sharks segregate into nursery areas for part of the year (Springer 1960, Medved \& Marshall 1983, Castro 1993, Merson \& Pratt 2001), but not in all parts of their range. Indeed, a study on the Western Australian coast found that juveniles were relatively more abundant in temperate compared to tropical waters (McAuley et al. 2007). The authors suggested that the Leeuwin Current, a poleward-flowing warm water current that dominates much of the Western Australia coast, provides a warm and stable temperature for juveniles and thus an increased opportunity for separation from the adult population. Furthermore, the correlation between the peak in distribution of juveniles and an extensive limestone reef system could also provide a habitat in which juveniles can take refuge from predators.

Depth gradients can provide opportunities for habitat partitioning particularly in coastal resident species such as Port Jackson sharks, where juveniles of both sexes use nursery areas in bays and estuaries and adults segregate by sex and use deeper water (McLaughlin \& O'Gower 1971). Similarly, young-ofthe-year grey nurse sharks use shallow-water reef habitat as a refuge from larger species (Dicken et al. 2006). Pikitch et al. (2005) found that small juvenile Caribbean reef sharks were relatively more common inside lagoons, and larger individuals used shallow fore-reef habitats near deeper water to increase foraging opportunities (Chapman et al. 2005). Small Caribbean reef sharks also move from shallow forereef habitats during the day into the lagoon at night presumably to reduce predation risk (Chapman et al. 2007). Similar behaviour has been observed at Midway Atoll, Hawaii, for juvenile Galápagos sharks Carcharhinus galapagensis, which use channels and forereef habitats during the day and move onto atoll flats at night (Lowe et al. 2006). Neonate nurse Ginglymostoma cirratum and lemon sharks also tend to use near-shore seagrass beds or other restricted areas more than their larger conspecifics (Gruber et al. 1988, Morrissey \& Gruber 1993a, Pikitch et al. 2005). This segregation might also be attributed to an ontogenetic dietary shift, whereby smaller prey items are available to juveniles in shallow areas.

Habitats are sometimes shared by both adults and juveniles; Heithaus et al. (2006) found no difference in microhabitat use between tiger sharks that were $<3.25 \mathrm{~m}$ TL and $>3.25 \mathrm{~m} \mathrm{TL}$, even though sexual segregation of juveniles exists (Heithaus 2001). Similarly, Carraro \& Gladstone (2006) did not find differences in microhabitat selection among age classes of ornate wobbegongs. Other species that share the same habitat among size classes do so by targeting differing food sources. For example, adult leopard sharks feed in nursery areas, although they shift from fish eggs to crustacean prey as they age (Ebert \& Ebert 2005).

Beyond simple descriptions of distribution patterns, few studies have examined habitat partitioning simultaneously among multiple species of coastal sharks (e.g. Nelson \& Johnson 1980, McKibben \& Nelson 1986). A study of habitat partitioning among inshore species in Western Australia found that sicklefin lemon Negaprion acutidens, spinner Carcharhinus brevipinna, blacktip and milk sharks Rhizoprionodon acutus share their habitat as a communal nursery, while nervous sharks $C$. cautus used the area for the duration of their life cycle (White \& Potter 2004). The concept of communal nursery areas is not new (Simpfendorfer \& Milward 1993), and they appear to be a common feature of many coastal areas (Castro 1993, Simpfendorfer \& Milward 1993, Yokota \& Lessa 2006). Temporal partitioning according to species size can also occur within the same nursery area (Yokota \& Lessa 2006) or other regions (White \& Potter 2004).

\section{CONSERVATION AND MANAGEMENT}

Sharks that are distributed in shallow near-shore waters are potentially at risk from a number of fishing sources (Field et al. 2009, Knip et al. 2009), such as bottom long line fisheries (e.g. Morgan et al. 2009), coastal 
trawl fisheries (as bycatch; Carbonell et al. 2003), gillnet fisheries (e.g. Stevens \& McLoughlin 1991, Trent et al. 1997), recreational fishing (Stevens et al. 2000a) and shark-control programs (e.g. Dudley et al. 2005). The depth at which sharks distribute themselves therefore has profound implications to their susceptibility to these sources. For example, long periods spent at the surface, as seen in whale sharks while in coastal aggregations, might leave them vulnerable to subsistence fisheries in developing countries or to being struck by vessels (Speed et al. 2008). Increased time spent at shallow depths at night by species such as Caribbean reef sharks (Chapman et al. 2007) and school sharks (West \& Stevens 2001) could also make them particularly susceptible to fishing during this period. Furthermore, the tendency for some species to segregate vertically by sex (e.g. lesser spotted dogfish; Sims et al. 2001) or age class (e.g. sandbar sharks; McAuley et al. 2007) make particular size classes more vulnerable to specific types of fishing gear. Vertical movement is undoubtedly an important aspect of habitat use that should be considered in management decisions; however, it is surprising that few studies have focused on 1 of the most common families of sharks in coastal areas, the Carcharhinidae (Fig. 2).

The effective conservation of coastal resident sharks can be achieved via the implementation of marine protected areas, because many species (or size classes) have relatively small home range sizes (i.e. $<100 \mathrm{~km}^{2}$ ). However, these protected areas are unlikely to encompass the entire range of a population (Kinney \& Simpfendorfer 2009). The potential use of protected areas to protect shark nursery areas has been examined (Heupel \& Simpfendorfer 2005b), and while considered useful, other measures must also be taken to protect older juvenile and adult life stages, such as a reduction in fishing capacity and size limits (Kinney \& Simpfendorfer 2009). Other areas might act as suitable sites for protected areas where multiple conspecifics or individuals of differing species cohabit with overlapping ranges or distribution (e.g. White \& Potter 2004, Chapman et al. 2005, Wiley \& Simpfendorfer 2007, DeAngelis et al. 2008).

An understanding of coastal migration patterns and population connectivity are essential for management (Bonfil 1997), although in many instances we lack this information. This is a greater management problem for coastal transient sharks that range widely (e.g. white, tiger, whale and basking sharks) and coastal resident sharks that migrate seasonally (e.g. grey nurse, blacktip and sandbar sharks), because these require both local and regional management coordination. The transoceanic movement of threatened species in particular requires international government cooperation and agreements to manage and conserve these wide-ranging species (Musick et al. 2000). Little is known about such long-distance movements, but in some instances, smaller coastal migration corridors could be established to assist the conservation of particular species.

The degree to which a species depends on a particular habitat (i.e. habitat specificity) also has profound implications for their management and conservation because threats to coastal environments are rising as a result of increased human population expansion and the development of coastal resources (Field et al. 2009). Sharks can select coastal habitats based on suitable environmental conditions such that localised degradation of important habitats will affect this process. The reduction in prey availability due to habitat degradation, over-harvesting or bycatch can also affect species that use this signal to select habitats (Wirsing et al. 2007). The extent and degree of site fidelity is also of particular relevance to the conservation of sharks (Heupel \& Simpfendorfer 2005b), as are population models that describe the level of habitat use or habitat dependency throughout a species' life (e.g. Springer 1967, Knip et al. 2010). The reason being, that marine protected areas might only be effective if the vulnerable age classes of a species are resident for long enough during their life cycle (Roberts 2000).

Even where closures assist in reducing extinction risk, they might not always be effective at reducing the probability of population decline. The ubiquity and variety of life stage segregations in coastal sharks has fostered a research focus on juvenile life stages in nursery areas, but clearly more information is required to determine the extent to which older, more mobile individuals are vulnerable to threats outside nurseries (e.g. Chapman et al. 2009). Where size-segregation occurs, other measures should therefore be used to protect these individuals. Myers \& Worm (2005) suggested that closures need to be combined with reduced fishing effort to avoid issues with relocation and displacement of effort. As such, they proposed 4 strategies to mitigate and remedy problems of overfishing: (1) reduction of fishing to avoid extinction of the most sensitive species, (2) reduction of bycatch mortality, (3) implementation of spatial closures and (4) establishment of permanent closures in important areas such as nurseries and mating areas. When aggregations are ephemeral, temporary enclosures could also be effective (Heupel \& Simpfendorfer 2005b). One such example is the implementation of a temporary closure for nurse sharks in Florida during their mating season (Carrier \& Pratt 1998).

\section{CONCLUSIONS}

Coastal sharks have become a subject of increasing research effort due to alarming decreases in popula- 
tion size (Shepherd \& Myers 2005, Myers et al. 2007), and the greater availability and affordability of monitoring technology. Most studies have been run over the short term; however, there has been a shift in focus toward longer-term research with the realisation that quantifying changes in habitat use over an individual's lifetime is essential for effective management and conservation. Some studies have also been attempting to monitor in situ environmental variables in conjunction with movement to provide more meaningful information on how sharks interact with their environment, which moves beyond the simple measurement of species presence or absence. The incorporation of new technologies is essential for enhancing our understanding of movement patterns, which is currently patchy for many species due to phenomena such as segregation of the sexes and life stages, and the limited scope and high cost of tracking techniques available in the past. The development and adoption of telemetry equipment that monitors environmental data as well as specific behavioural information over long periods will allow us to shift focus from habitat-specific monitoring to a full life-stage approach.

Our review highlights that despite a growing body of general information describing the temporal and spatial patterns of shark movements, there have still been far too few (temporally and spatially) data collected to be able to make sweeping statements regarding the best ways to manage sharks. In particular, there is a lack of vertical movement information for sharks that are coastal residents, which is a potential hindrance to their successful management and conservation. General vertical patterns that have been obtained from coastal transient sharks while in coastal areas (i.e. oscillatory vertical displacements, surface swimming, diel vertical migration and swimming at depth) are usually attributed to foraging or navigation. Horizontal movement patterns have been well documented for many coastal sharks, although differences in data collection and analysis methods complicate making broad generalisations about these patterns. Nevertheless, our meta-analysis lends support to the concept that home range size increases as a function of body size as well as monitoring time. As monitoring technology becomes more widely accessible, standardised analysis techniques will hopefully be employed, which will further facilitate size comparisons across size classes and species for conservation and management.

The environmental factors that drive fine- and largescale movement patterns have been identified for some species, although other ontogenetic and biotic factors have been relatively poorly documented. The consequences of these movement patterns often result in site fidelity to localised coastal areas, although definitions of the nature of these relationships are often inconsistent within the literature, making conclusions about these phenomena tenuous. Therefore, a standardisation of terminology and additional use of qualifiers to denote the exact extent of site fidelity is suggested. Data on segregation and habitat partitioning, which are important considerations in the design of successful protected areas, are also scarce.

To provide a more complete and meaningful representation of coastal shark movement patterns for conservation and management planning, we suggest that the following areas of research should be made priorities: (1) the quantification of long-term vertical and horizontal habitat use, (2) further research on ontogenetic and biotic relationships with movement patterns, (3) migration and dispersal capacity, (4) natal site fidelity and (5) habitat partitioning within and among species. Armed with precise information describing these aspects of coastal shark ecology and behaviour for sympatric species, we will have the chance to minimise the effects of marine degradation on these vulnerable populations.

Acknowledgements. We thank the Australian Institute of Marine Science, Charles Darwin University, The University of Adelaide, and Macquarie University for their ongoing support and assistance. We thank R. Fisher for assistance with mapping.

\section{LITERATURE CITED}

Ackerman JT, Kondratieff MC, Matern SA, Cech JJ (2000) Tidal influence on spatial dynamics of leopard sharks, Triakis semifasciata, in Tomales Bay, California. Environ Biol Fishes 58:33-43

Andrews KS, Levin PS, Kats SL, Farrer D, Gallucci VF, Bargmann G (2007) Acoustic monitoring of sixgill shark movements in Puget Sound: evidence for localised movement. Can J Zool 85:1136-1142

Andrews KS, Williams GD, Farrer D, Tolimieri N, Harvey CJ, Bargmann G, Levin PS (2009) Diel activity patterns of sixgill sharks, Hexanchus griseus: the ups and downs of an apex predator. Anim Behav 78:525-536

Bansemer CS, Bennett MB (2009) Reproductive periodicity, localised movements and behavioural segregation of pregnant Carcharias taurus at Wolf Rock, southeast Queensland, Australia. Mar Ecol Prog Ser 374:215-227

Bascompte J, Melian CJ, Sala E (2005) Interaction strength combinations and the overfishing of a marine food web. Proc Natl Acad Sci USA 102:5443-5447

Bollens SM, Frost BW (1989) Predator-induced diel vertical migration in a planktonic copepod. J Plankton Res 11: 1047-1075

Bonfil R (1997) Status of shark resources in the Southern Gulf of Mexico and Caribbean: implications for management. Fish Res 29:101-117

- Bonfil R, Meyer MM, Scholl MC, Johnson R and others (2005) Transoceanic migration, spatial dynamics, and population linkages of white sharks. Science 310:100-103

Boustany AM, Davis SF, Pyle P, Anderson SD, Le Boeuf BJ, Block BA (2002) Expanded niche for white sharks. Nature 415:35-36 
Bradshaw CJA, Giam X, Tan HTW, Brook BW, Sodhi NS (2008) Threat or invasive status in legumes is related to opposite extremes of the same ecological and life history attributes. J Ecol 96:869-883

Branstetter S (1990) Early life-history implications of selected carcharinoid and lamnoid sharks of the northwest Atlantic. NOAA Tech Rep NMFS 90:17-28

Bres M (1993) The behaviour of sharks. Rev Fish Biol Fish 3: 133-159

Brook BW, Sodhi NS, Bradshaw CJA (2008) Synergies among extinction drivers under global change. Trends Ecol Evol 23:453-460

Bruce BD, Stevens JD, Malcom H (2006) Movements and swimming behaviour of white sharks (Carcharodon carcharias) in Australian waters. Mar Biol 150:161-172

Brunnschweiler JM, Baensch H, Pierce SJ, Sims DW (2009) Deep-diving behaviour of a whale shark Rhincodon typus during long-distance movement in the western Indian Ocean. J Fish Biol 74:706-714

Burnham KP, Anderson DR (2002) Model selection and multimodal inference: a practical information-theoretic approach, 2nd edn. Springer-Verlag, New York, NY

> Cailliet GM (1992) Demography of the central California population of the leopard shark (Triakis semifasciata). Aust J Mar Freshw Res 43:183-193

Campos BR, Fish MA, Jones G, Riley RW and others (2009) Movements of brown smoothhounds, Mustelus henlei, in Tomales Bay, California. Environ Biol Fishes 85:3-13

Carbonell A, Alemany F, Merella P, Quetglas A, Roman E (2003) The by-catch of sharks in the western Mediterranean (Balearic Islands) trawl fishery. Fish Res 61:7-18

> Carlisle AB, Starr RM (2009) Habitat use, residency, and seasonal distribution of female leopard sharks Triakis semifasciata in Elkhorn Slough, California. Mar Ecol Prog Ser 380:213-228

> Carlson JK, Heupel MR, Bethea DM, Hollensead LD (2008) Coastal habitat use and residency of juvenile Atlantic sharpnose sharks (Rhizoprionodon terraenovae). Estuaries Coasts 31:931-940

Carraro R, Gladstone W (2006) Habitat preferences and site fidelity of the ornate wobbegong shark (Orectolobus ornatus) on rocky reefs of New South Wales. Pac Sci 60: 207-223

- Carrier JC, Pratt HL (1998) Habitat management and closure of a nurse shark breeding and nursery ground. Fish Res 39:209-213

> Castro JI (1993) The shark nursery of Bulls Bay, South Carolina, with a review of the shark nurseries of the southeastern coast of the United States. Environ Biol Fishes 38: $37-48$

- Chapman DD, Pikitch EK, Babcock E, Shivji MS (2005) Marine reserve design and evaluation using automated acoustic telemetry: a case study involving coral reefassociated sharks in the Mesoamerican Caribbean. Mar Technol Soc J 39:42-55

> Chapman DD, Pikitch EK, Babcock EA, Shivji MS (2007) Deep-diving and diel changes in vertical habitat use by Caribbean reef sharks Carcharhinus perezi. Mar Ecol Prog Ser 344:271-275

> Chapman DD, Babcock EA, Gruber SH, Dibattista JD and others (2009) Long-term natal site-fidelity by immature lemon sharks (Negaprion brevirostris) at a subtropical island. Mol Ecol 18:3500-3507

> Colman JG (1997) A review of the biology and ecology of the whale shark. J Fish Biol 51:1219-1234

> Compagno LJV (1990) Alternative life-history styles of cartilaginous fishes in time and space. Environ Biol Fishes 28:33-75
Conrath CL, Musick JA (2008) Investigations into depth and temperature habitat utilization and overwintering grounds of juvenile sandbar sharks, Carcharhinus plumbeus: the importance of near shore North Carolina waters. Environ Biol Fishes 82:123-131

Cortes E (1999a) Standardized diet compositions and trophic levels of sharks. ICES J Mar Sci 56:707-717

Cortes E (1999b) A stochastic stage-based population model of the sandbar shark in the western north Atlantic. In: Musick JA (ed) Life in the slow lane: ecology and conservation of long lived marine animals. Am Fish Soc Symp 23, Bethesda, MD, p 115-136

Cortes E (2000) Life history patterns and correlations in sharks. Rev Fish Sci 8:299-344

> DeAngelis BM, McCandless CT, Kohler NE, Recksiek CW, Skomal GB (2008) First characterization of shark nursery habitat in the United States Virgin Islands: evidence of habitat partitioning by two shark species. Mar Ecol Prog Ser 358:257-271

Dicken ML, Smale MJ, Booth DJ (2006) Spatial and seasonal distribution patterns of the ragged-tooth sharks Carcharias taurus along the coast of South Africa. Afr J Mar Sci 28:603-616

Dicken ML, Booth DJ, Smale MJ, Cliff G (2007) Spatial and seasonal distribution patterns of juvenile and adult raggedtooth sharks (Carcharias taurus) tagged off the east coast of South Africa. Mar Freshw Res 58:127-134

Domeier ML, Nasby-Lucas N (2008) Migration patterns of white sharks Carcharodon carcharias tagged at Guadalupe Island, Mexico, and identification of an eastern Pacific shared offshore foraging area. Mar Ecol Prog Ser 370:221-237

Dudley SFJ, Cliff G, Zungu MP, Smale MJ (2005) Sharks caught in the protective gill nets of KwaZulu-Natal, South Africa. 10. The dusky shark Carcharhinus obscurus (Lesueur 1818). Afr J Mar Sci 27:107-127

> Duncan KM, Holland KN (2006) Habitat use, growth rates and dispersal patterns of juvenile scalloped hammerhead sharks Sphyrna lewini in a nursery habitat. Mar Ecol Prog Ser 312:211-221

- Ebert DA, Ebert TB (2005) Reproduction, diet and habitat use of leopard sharks, Triakis semifasciata (Girard), in Humboldt Bay, California, USA. Mar Freshw Res 56:1089-1098

Eckert SA, Stewart BS (2001) Telemetry and satellite tracking of whale sharks, Rhincodon typus, in the Sea of Cortez, Mexico, and the north Pacific Ocean. Environ Biol Fishes 60:299-308

Eckert SA, Dolar LL, Kooyman GL, Perrin W, Rahman RA (2002) Movements of whale sharks (Rhincodon typus) in South-east Asian waters as determined by satellite telemetry. J Zool 257:111-115

Economakis AE, Lobel PS (1998) Aggregation behavior of the grey reef shark, Carcharhinus amblyrhynchos, at Johnston Atoll, Central Pacific Ocean. Environ Biol Fishes 51:129-139

> Edren SMC, Gruber SH (2005) Homing ability of young lemon sharks, Negaprion brevirostris. Environ Biol Fishes 72:267-281

Field IC, Bradshaw CJA, Burton HR, Sumner MD, Hindell MA (2005) Resource partitioning through oceanic segregation of foraging juvenile southern elephant seals. Oecologia 142:127-135

Field IC, Meekan M, Buckworth RC, Bradshaw CJA (2009) Susceptibility of sharks, rays and chimaeras to global extinction. Adv Mar Biol 56:275-363

Fogarty MJ, Murawski SA (1998) Large-scale disturbance and the structure of marine systems: fishery impacts on the Georges Bank. Ecol Appl 8 (Suppl):s6-s22 
Friedlander AM, DeMartini EE (2002) Contrasts in density, size, and biomass of reef fishes between the northwestern and the main Hawaiian islands: the effects of fishing down apex predators. Mar Ecol Prog Ser 230:253-264

Froese R, Pauly D (eds) (2010) FishBase. www.fishbase.org

> Garcia VB, Lucifora LO, Myers RA (2008) The importance of habitat and life history to extinction risk in sharks, skates, rays and chimeras. Proc Biol Sci 275:83-89

Garla RC, Chapman DD, Wetherbee BM, Shivji MS (2006) Movement patterns of young Caribbean reef sharks, Carcharhinus perezi, at Fernando de Noronha Archipelago, Brazil: the potential of marine protected areas for conservation of a nursery ground. Mar Biol 149:189-199

- Goldman KJ, Anderson DR (1999) Space utilization and swimming depth of white sharks, Carcharodon carcharias, at the South Farallon Islands, central California. Environ Biol Fishes 56:351-364

Gore MA, Rowat D, Hall J, Gell FR, Ormond RF (2008) Transatlantic migration and deep mid-ocean diving by basking shark. Biol Lett 4:395-398

- Graham RT, Roberts CM (2007) Assessing the size, growth rate and structure of a seasonal population of whale sharks (Rhincodon typus) using conventional tagging and photo identification. Fish Res 84:71-80

Graham RT, Roberts CM, Smart JCR (2006) Diving behaviour of whale sharks in relation to a predicted food pulse. J R Soc Interface 3:109-116

Gruber SH, Nelson DR, Morrissey JF (1988) Patterns of activity and space utilization of lemon sharks, Negaprion brevirostris, in a shallow Bahamian lagoon. Bull Mar Sci 43:61-76

Gunn JS, Stevens JD, Davis TLO, Norman BM (1999) Observations on the short-term movements and behaviour of whale sharks (Rhincodon typus) at Ningaloo Reef, Western Australia. Mar Biol 135:553-559

Heithaus MR (2001) The biology of tiger sharks, Galeocerdo cuvier, in Shark Bay, Western Australia: sex ratio, size distribution, diet, and seasonal changes in catch rates. Environ Biol Fishes 61:25-36

- Heithaus MR, Dill LM, Marshall GJ, Buhleier BM (2002) Habitat use and foraging behavior of tiger sharks (Galeocerdo cuvier) in a seagrass ecosystem. Mar Biol 140: 237-248

> Heithaus MR, Hamilton IM, Wirsing AJ, Dill LM (2006) Validation of a randomization procedure to assess animal habitat preference: microhabitat use of tiger sharks in a seagrass ecosystem. J Anim Ecol 75:666-676

Heithaus MR, Wirsing AJ, Dill LM, Heithaus LI (2007) Longterm movements of tiger sharks satellite-tagged in Shark Bay, Western Australia. Mar Biol 151:1455-1461

Heithaus MR, Frid A, Wirsing AJ, Worm B (2008) Predicting ecological consequences of marine top predator declines. Trends Ecol Evol 23:202-210

Heithaus MR, Delius BK, Wirsing AJ, Dunphy-Daly MM (2009a) Physical factors influencing the distribution of a top predator in a subtropical oligotrophic estuary. Limnol Oceanogr 54:472-482

> Heithaus MR, Wirsing AJ, Burkholder D, Thomson J, Dill LM (2009b) Towards a predictive framework for predator risk effects: the interaction of landscape features and prey escape tactics. J Anim Ecol 78:556-562

Herrel A, Gibb AC (2006) Ontogeny of performance in vertebrates. Physiol Biochem Zool 79:1-6

Heupel MR, Hueter RE (2001) Use of an automated acoustic telemetry system to passively track juvenile blacktip shark movements. In: Sibert JR, Nielsen JL (eds) Electronic tagging and tracking in marine fisheries. Kluwer Academic Publishers, Dordrecht, p 217-234
Heupel MR, Hueter RE (2002) Importance of prey density in relation to the movement patterns of juvenile blacktip sharks (Carcharhinus limbatus). Mar Freshw Res 53:543-550

> Heupel MR, Simpfendorfer CA (2005a) Quantitative analysis of aggregation behavior in juvenile blacktip sharks. Mar Biol 147:1239-1249

> Heupel MR, Simpfendorfer CA (2005b) Using acoustic monitoring to evaluate MPAs for shark nursery areas: the importance of long-term data. Mar Technol Soc J 39:10-18

> Heupel MR, Simpfendorfer CA (2008) Movement and distribution of young bull sharks Carcharhinus leucas in a variable estuarine environment. Aquat Biol 1:277-289

> Heupel MR, Simpfendorfer CA, Hueter RE (2003) Running before the storm: blacktip sharks respond to falling barometric pressure associated with Tropical Storm Gabrielle. J Fish Biol 63:1357-1363

Heupel MR, Simpfendorfer CA, Hueter RE (2004) Estimation of shark home ranges using passive monitoring techniques. Environ Biol Fishes 71:135-142

> Heupel MR, Semmens JM, Hobday AJ (2006a) Automated acoustic tracking of aquatic animals: scales, design, and deployment of listening station arrays. Mar Freshw Res 57: $1-13$

Heupel MR, Simpfendorfer CA, Collins AB, Tyminski JP (2006b) Residency and movement patterns of bonnethead sharks, Sphyrna tiburo, in a large Florida estuary. Environ Biol Fishes 76:47-67

Heupel MR, Carlson JK, Simpfendorfer CA (2007) Shark nursery areas: concepts, definition, characterization and assumptions. Mar Ecol Prog Ser 337:287-297

> Heupel MR, Williams AJ, Welch DJ, Ballagh A and others (2009) Effects of fishing on tropical reef associated shark populations on the Great Barrier Reef. Fish Res 95: 350-361

Heupel MR, Simpfendorfer CA, Fitzpatrick R (2010) Largescale movement and reef fidelity of grey reef sharks. PLoS ONE 5:e9650

> Hight BV, Lowe CG (2007) Elevated body temperatures of adult female leopard sharks, Triakis semifasciata, while aggregating in shallow nearshore embayments: Evidence for behavioural thermoregulation? J Exp Mar Biol Ecol 352:114-128

Holland KN, Lowe CG, Peterson JD, Gill A (1992) Tracking coastal sharks with small boats: hammerhead shark pups as a case study. Aust J Mar Freshw Res 43:61-66

> Holland KN, Wetherbee BM, Peterson JD, Lowe CG (1993) Movements and distribution of hammerhead shark pups on their natal grounds. Copeia 1993:495-502

> Holland KN, Wetherbee BM, Lowe CG, Meyer CG (1999) Movements of tiger sharks (Galeocerdo cuvier). Mar Biol 134:665-673

> Hopkins TE, Cech JJJ (2003) The influence of environmental variables on the distribution and abundance of three elasmobranchs in Tomales Bay, California. Environ Biol Fishes 66:279-291

Hsu HH, Joung SJ, Liao YY, Liu KM (2007) Satellite tracking of juvenile whale sharks, Rhincodon typus, in the Northwestern Pacific. Fish Res 84:25-31

Hueter RE, Manire CA (1994) Bycatch and catch-release mortality of small sharks in the Gulf Coast nursery grounds of Tampa Bay and Charlotte Harbor. Mote Mar Tech Rep No. 368 (final report to NOAA/NMFS, MARFIN Project NA17FF0378-01, Florida)

- Hueter RE, Heupel MR, Heist EJ, Keeney DB (2004) Evidence of philopatry in sharks and implications for the management of shark fisheries. J Northwest Atl Fish Sci 35: $239-247$ 
Hulbert LB, Sigler MF, Lunsford CR (2006) Depth and movement behaviour of the Pacific sleeper shark in the northeast Pacific Ocean. J Fish Biol 69:406-425

Hurst RJ, Bagley NW, McGregor GA, Francis MP (1999) Movements of the New Zealand school shark, Galeorhinus galeus, from tag returns. N Z J Mar Freshw Res 33: $29-48$

Hussey NE, McCarthy ID, Dudley SFJ, Mann BQ (2009) Nursery grounds, movement patterns and growth rates of dusky sharks, Carcharhinus obscurus: a long-term tag and release study in South African waters. Mar Freshw Res 60: $571-583$

Huveneers C, Harcourt RG, Otway NM (2006) Observations of localised movements and residence times of the wobbegong shark Orectolobus halei at Fish Rock, NSW, Australia. Cybium 30:103-111

IMOS (Integrated Marine Observing System) (2009) Australian Animal Tagging and Monitoring System (AATAMS). http://imos.org.au/aatams.html

> Jackson JBC, Kirby MX, Berger WH, Bjorndal KA and others (2001) Historical overfishing and the recent collapse of coastal ecosystems. Science 293:629-638

> Jarman SN, Wilson SG (2004) DNA-based species identification of krill consumed by whale sharks. J Fish Biol 65: 586-591

Johnson R, Bester MN, Dudley SFJ, Oosthuizen WH, Meyer M, Hancke L, Gennari E (2009) Coastal swimming patterns of white sharks (Carcharodon carcharias) at Mossel Bay, South Africa. Environ Biol Fishes 85:189-200

Jorgensen SJ, Klimley AP, Muhlia-Melo AF (2009) Scalloped hammerhead shark, Sphyrna lewini, utilizes deep-water, hypoxic zone in the Gulf of California. J Fish Biol 74: 1682-1687

Kinney MJ, Simpfendorfer CA (2009) Reassessing the value of nursery areas to shark conservation and management. Conserv Lett 2:53-60

Klimley AP (1993) Highly directional swimming by scalloped hammerhead sharks, Sphyrna lewini, and subsurface irradiance, temperature, bathymetry, and geomagnetic field. Mar Biol 117:1-22

Klimley PA, Nelson DR (1984) Diel movement patterns of the scalloped hammerhead shark (Sphyrna lewini) in relation to El Bajo Espirito Santo: a refuging central-position social system. Behav Ecol Sociobiol 15:45-54

Klimley PA, Butler SB, Nelson DR, Stull AT (1988) Diel movements of scalloped hammerhead sharks, Sphyrna lewini Griffith and Smith, to and from a seamount in the Gulf of California. J Fish Biol 33:751-761

Klimley PA, Beavers SC, Curtis TH, Jorgensen SJ (2002) Movements and swimming behavior of three species of sharks in La Jolla Canyon, California. Environ Biol Fishes 63:117-135

Knip DM, Heupel MR, Simpfendorfer CA (2010) Sharks in nearshore environments: models, importance, and consequences. Mar Ecol Prog Ser 402:1-11

Kohler NE, Turner PA (1998) NMFS cooperative shark tagging program, 1962-93: an atlas of shark tag and recapture data. Mar Fish Rev 60:1-87

Lowe CG, Wetherbee BM, Meyer CG (2006) Using acoustic telemetry monitoring techniques to quantify movement patterns and site fidelity of sharks and giant trevally around French Frigate Shoals and Midway Atoll. Atoll Res Bull 543:281-303

> McAuley RB, Simpfendorfer CA, Hyndes GA, Lenanton RCJ (2007) Distribution and reproductive biology of the sandbar shark, Carcharhinus plumbeus (Nardo), in Western Australian waters. Mar Freshw Res 58:116-126
McCord ME, Lamberth SJ (2009) Catching and tracking the world's largest Zambezi (bull) shark Carcharhinus leucas in the Breede Estuary, South Africa: the first 43 hours. Afr J Mar Sci 31:107-111

McKibben JN, Nelson DR (1986) Patterns of movement and grouping of gray reef sharks, Carcharhinus amblyrhynchos, at Enewetak, Marshall Island. Bull Mar Sci 38: 89-110

McLaughlin RH, O'Gower AK (1971) Life history and underwater studies of a heterodont shark. Ecol Monogr 41: 271-289

> McNab BK (1963) Bioenergetics and the determination of home range size. Am Nat 97:133-140

Medved RJ, Marshall JA (1983) Short-term movements of young sandbar sharks, Carcharhinus plumbeus (Pisces, Carcharhinidae). Bull Mar Sci 33:87-93

Meekan MG, Bradshaw CJA, Press M, McLean C, Richards A, Quasnichka S, Taylor JG (2006) Population size and structure of whale sharks (Rhincodon typus) at Ningaloo Reef, Western Australia. Mar Ecol Prog Ser 319: 275-285

> Merson RR, Pratt JHL (2001) Distribution, movements and growth of young sandbar sharks, Carcharhinus plumbeus, in the nursery grounds of Delaware Bay. Environ Biol Fishes 61:13-24

Meyer CG, Clark TB, Papastamatiou YP, Whitney NM, Holland KN (2009) Long-term movement patterns of tiger sharks Galeocerdo cuvier in Hawaii. Mar Ecol Prog Ser 381:223-235

Morgan A, Cooper PW, Curtis T, Burgess GH (2009) Overview of the U.S east coast bottom longline shark fishery, 1994-2003. Mar Fish Rev 71:23-38

Morrissey JF, Gruber SH (1993a) Habitat selection by juvenile lemon sharks, Negaprion brevirostris. Environ Biol Fishes 38:311-319

> Morrissey JF, Gruber SH (1993b) Home range of juvenile lemon sharks, Negaprion brevirostris. Copeia 1993: 425-434

Musick JA, Burgess G, Cailliet GM, Camhi M, Fordham S (2000) Management of sharks and their relatives (Elasmobranchii). Fisheries 25:9-13

Myers RA, Worm B (2003) Rapid worldwide depletion of predatory fish communities. Nature 423:280-283

Myers RA, Worm B (2005) Extinction, survival or recovery of large predatory fishes. Philos Trans R Soc B Biol Sci 360: $13-20$

Myers RA, Baum JK, Shepherd TD, Powers SP, Peterson CH (2007) Cascading effects of the loss of apex predatory sharks from a coastal ocean. Science 315:1846-1850

Nelson DR (1977) On the field study of shark behavior. Am Zool 17:501-507

Nelson DR (1990) Telemetry studies of sharks: a review, with applications in resource management. NMFS, NOAA Tech Rep 90:39-56

Nelson DR, Johnson RH (1980) Behavior of reef sharks of Rangiroa, French Polynesia. Natl Geogr Soc Res Rep 12: 479-499

O'Gower AK (1995) Speculations on a spatial memory for the Port Jackson shark (Heterodontus portusjacksoni) (Meyer) (Heterodontidae). Mar Freshw Res 46:861-871

Olsen AM (1954) The biology, migration and growth rate of the school shark (Galeorhinus australis) (Macleay) (Carcharhinidae) in south-eastern Australian waters. Aust J Mar Freshw Res 5:353-410

Pace ML, Cole JJ, Carpenter SR, Kitchell JF (1999) Trophic cascades revealed in diverse ecosystems. Trends Ecol Evol $14: 483-488$ 
Papastamatiou YP, Lowe CG, Caselle JE, Friedlander AM (2009) Scale-dependent effects of habitat on movement and path structure of reef sharks at a predator-dominated atoll. Ecology 90:996-1008

Pikitch EK, Chapman DD, Babcock E, Shivji MS (2005) Habitat use and demographic population structure of elasmobranchs at a Caribbean atoll (Glover's Reef, Belize). Mar Ecol Prog Ser 302:187-197

Pratt HL Jr, Carrier JC (2001) A review of elasmobranch reproductive behavior with a case study on the nurse shark, Ginglymostoma cirratum. Environ Biol Fishes 60: $157-188$

Priede IG (1984) A basking shark (Cetorhinus maximus) tracked by satellite together with simultaneous remote sensing. Fish Res 2:201-216

> Priede IG, Miller PI (2009) A basking shark (Cetorhinus maximus) tracked by satellite together with simultaneous remote sensing II: New analysis reveals orientation to a thermal front. Fish Res 95:370-372

Rabinowitz D, Cairns S, Dillon T (1986) Seven forms of rarity and their frequency in the flora of the British Isles. In: Soulé ME (ed) Conservation biology: the science of scarcity and diversity. Sinauer Associates, Sunderland, MA, p 182-284

> Rechisky EL, Wetherbee BM (2003) Short-term movements of juvenile and neonate sandbar sharks, Carcharhinus plumbeus, on their nursery ground in Delaware Bay. Environ Biol Fishes 68:113-128

Robbins WD, Hisano M, Connolly SR, Choat HJ (2006) Ongoing collapse of coral-reef shark populations. Curr Biol 16: 2314-2319

Roberts CM (2000) Selecting marine reserve locations: optimality versus opportunism. Bull Mar Sci 66:581-592

Rowat D, Gore M (2007) Regional scale horizontal and local scale vertical movements of whale sharks in the Indian Ocean off Seychelles. Fish Res 84:32-40

Rowat D, Meekan M, Engelhardt U, Pardigon B, Vely M (2007) Aggregations of juvenile whale sharks (Rhincodon typus) in the Gulf of Tadjoura, Djibouti. Environ Biol Fishes 80:465-472

Sandin SA, Smith JE, DeMartini EE, Dinsdale EA and others (2008) Baselines and degradation of coral reefs in the Northern Line Islands. PLoS ONE 3:e1548

Shepard ELC, Ahmed MZ, Southall EJ, Witt MJ, Metcalfe JD, Sims DW (2006) Diel and tidal rhythms in diving behaviour of pelagic sharks identified by signal processing of archival data. Mar Ecol Prog Ser 328:205-213

> Shepherd TD, Myers RA (2005) Direct and indirect fishery effects on small coastal elasmobranchs in the northern Gulf of Mexico. Ecol Lett 8:1095-1104

Simpfendorfer CA, Heupel MR (2004) Assessing habitat use and movement. In: Carrier JC, Musick JA, Heithaus MR (eds) Biology of sharks and their relatives. CRC Press, Boca Raton, p 553-572

Simpfendorfer CA, Milward NE (1993) Utilisation of a tropical bay as a nursery area by sharks of the families Sarcharhinidae and Sphyrnidae. Environ Biol Fishes 37: 337-345

Simpfendorfer CA, Freitas GG, Wiley TR, Heupel MR (2005) Distribution and habitat partitioning of immature bull sharks (Carcharhinus leucas) in a southwest Florida estuary. Estuaries 28:78-85

Sims DW (2003) Tractable models for testing theories about natural strategies: foraging behaviour and habitat selection of free-ranging sharks. J Fish Biol 63 (Suppl A):53-73

Sims DW (2005) Differences in habitat selection and reproductive strategies of male and female sharks. In: Ruck- stuhl KE, Neuhaus P (eds) Sexual segregation in vertebrates: ecology of the two sexes. Cambridge University Press, Cambridge

> Sims DW (2008) Sieving a living: a review of the biology, ecology and conservation status of the plankton-feeding basking shark Cetorhinus maximus. Adv Mar Biol 54:171-220

Sims DW, Quayle VA (1998) Selective foraging behaviour of basking sharks on zooplankton in a small-scale front. Nature 393:460-464

Sims DW, Nash JP, Morritt D (2001) Movements and activity of male and female dogfish in a tidal sea lough: alternative behavioural strategies and apparent sexual segregation. Mar Biol 139:1165-1175

> Sims DW, Southall EJ, Richardson AJ, Reid PC, Metcalfe JD (2003) Seasonal movements and behaviour of basking sharks from archival tagging: no evidence of winter hibernation. Mar Ecol Prog Ser 248:187-196

Sims DW, Southall EJ, Tarling GA, Metcalfe JD (2005a) Habitat-specific normal and reverse diel vertical migration in the plankton-feeding basking shark. J Anim Ecol 74: 755-761

Sims DW, Southall EJ, Wearmouth VJ, Hutchinson N, Budd GC, Morritt D (2005b) Refuging behaviour in the nursehound Scyliorhinus stellaris (Chondrichthyes: Elasmobranchii): preliminary evidence from acoustic telemetry. J Mar Biol Assoc UK 85:1137-1140

Sims DW, Wearmouth VJ, Southall EJ, Hill JM and others (2006) Hunt warm, rest cool: bioenergetic strategy underlying diel vertical migration of a benthic shark. J Anim Ecol 75:176-190

- Sims DW, Southall EJ, Humphries NE, Hays GC and others (2008) Scaling laws of marine predator search behaviour. Nature 451:1098-1102

Skomal GB, Wood G, Caloyianis N (2004) Archival tagging of a basking shark, Cetorhinus maximus, in the western North Atlantic. J Mar Biol Assoc UK 84:795-799

Skomal GB, Zeeman SI, Chisholm JH, Summers EL, Walsh HJ, McMahon KW, Thorrold SR (2009) Transequatorial migrations by basking sharks in the western Atlantic Ocean. Curr Biol 19:1019-1022

Sodhi NS, Bickford D, Diesmos AC, Lee TM, Koh LP, Brook BW, Sekercioglu CH, Bradshaw CJA (2008a) Measuring the meltdown: drivers of global amphibian extinction and decline. PLoS ONE 3:e1636

> Sodhi NS, Koh LP, Peh KSH, Tan HTW and others (2008b) Correlates of extinction proneness in tropical angiosperms. Divers Distrib 14:1-10

Speed CW, Meekan M, Rowat D, Pierce SJ, Marshall AD, Bradshaw CJA (2008) Scarring patterns and relative mortality rates of Indian Ocean whale sharks. J Fish Biol 72: $1488-1503$

Springer S (1960) Natural history of the sandbar shark Eulamia milberti. Fish Bull 61:1-38

Springer S (1967) Social organisation in shark populations. In: Gilbert PW, Mathewson RF, Rall DP (eds) Sharks, skates and rays. Johns Hopkins University Press, Baltimore, MD, p 149-174

Standora EA, Nelson DR (1977) A telemetric study of the behavior of free-swimming pacific angle sharks, Squatina californica. Bull Southern California Acad Sci 76: 193-201

> Stevens JD (1984) Life-history and ecology of sharks at Aldabra Atoll, Indian Ocean. Proc R Soc Lond B Biol Sci 222:79-106

Stevens JD, McLoughlin KJ (1991) Distribution, size and sex composition, reproductive biology and diet of sharks from Northern Australia. Aust J Mar Freshw Res 42:151-199 
Stevens JD, Bonfil R, Dulvy NK, Walker PA (2000a) The effects of fishing on sharks, rays and chimaeras (chondrichthyans), and the implications for marine ecosystems. ICES J Mar Sci 57:476-494

Stevens JD, West GJ, McLoughlin KJ (2000b) Movements, recapture patterns, and factors affecting the return rate of carcharhinid and other sharks tagged off northern Australia. Mar Freshw Res 51:127-141

Stokesbury MJW, Harvey-Clark C, Gallant G, Block BA, Myers RA (2005) Movement and environmental preferences of the Greenland sharks (Somniosus microcephalus) electronically tagged in the St. Lawrence Estuary, Canada. Mar Biol 148:159-165

Strong WR, Bruce BD, Nelson DR, Murphy RD (1996) Population dynamics of white sharks in Spencer Gulf, South Australia. In: Klimley AP, Ainley DG (eds) Great white sharks: the biology of Carcharodon carcharias. Academic Press, San Diego, CA, p 401-414

Sundström LF, Gruber SH, Clermont SM, Correia JPS and others (2001) Reivew of elasmobranch behavioral studies using ultrasonic telemetry with special reference to the lemon shark, Negaprion brevirostris, around Bimini Islands, Bahamas. Environ Biol Fishes 60:225-250

Thorson TB (1971) Movement of bull sharks, Carcharhinus leucas, between Caribbean Sea and Lake Nicaragua demonstrated by tagging. Copeia 2 (1971):336-338

Trent L, Parshley DE, Carlson JK (1997) Catch and bycatch in the shark drift gillnet fishery off Georgia and east Florida. Mar Fish Rev 59:19-28

Tricas TC (1981) Diel behavior of the tiger shark, Galeocerdo cuvier, at French Frigate Shoals, Hawaiian Islands. Copeia 1981:904-908

Ubeda AJ, Simpfendorfer CA, Heupel MR (2009) Movements of bonnetheads, Sphyrna tiburo, as a response to salinity change in a Florida estuary. Environ Biol Fishes 84: 293-303

Vogler R, Milessi AC, Quinones A (2008) Influence of environmental variables on the distribution of Squatina guggenheim (Chondrichthyes, Squatinidae). Fish Res 91: 212-221

Walker TI (1998) Can shark resources be harvested sustainably? A question revisited with a review of shark fisheries. Mar Freshw Res 49:553-572

Watts ME, Ball IR, Stewart RS, Klein CJ and others (2009) Marxan with zones: software for optimal conservation

Editorial responsibility: John Choat,

Townsville, Australia based land- and sea-use zoning. Environ Model Softw 24: 1513-1521

Weng KC, Boustany AM, Pyle P, Anderson SD, Brown A, Block BA (2007a) Migration and habitat of white sharks (Carcharodon carcharias) in the eastern Pacific Ocean. Mar Biol 152:877-894

> Weng KC, O'Sullivan JB, Lowe CG, Winkler CE, Dewar H, Block BA (2007b) Movements, behavior and habitat preferences of juvenile white sharks Carcharodon carcharias in the eastern Pacific. Mar Ecol Prog Ser 338:211-224

- West GJ, Stevens JD (2001) Archival tagging of school shark, Galeorhinus galeus, in Australia: initial results. Environ Biol Fishes 60:283-298

Wetherbee BM, Crow GL, Lowe CG (1996) Biology of the Galapagos shark, Carcharhinus galapagensis, in Hawai'i. Environ Biol Fishes 45:299-310

Wetherbee BM, Gruber SH, Rosa RS (2007) Movement patterns of juvenile lemon sharks Negaprion brevirostris within Atol das Rocas, Brazil: a nursery characterized by tidal extremes. Mar Ecol Prog Ser 343:283-293

White WT, Potter IC (2004) Habitat partitioning among four elasmobranch species in nearshore, shallow waters of a subtropical embayment in Western Australia. Mar Biol 145:1023-1032

Whitney NM, Papastamatiou YP, Holland KN, Lowe CG (2007) Use of an acceleration data logger to measure diel activity patterns in captive whitetip sharks, Triaenodon obesus. Aquat Living Resour 20:299-305

Wiley TR, Simpfendorfer CA (2007) The ecology of elasmobranchs occurring in the Everglades National Park, Florida: implications for conservation and management. Bull Mar Sci 80:171-189

Wilson SG, Polovina JJ, Stewart BS, Meekan MG (2006) Movement of whale sharks (Rhincodon typus) tagged at Ningaloo Reef, Western Australia. Mar Biol 148: 1157-1166

Wirsing AJ, Heithaus MR, Dill LM (2007) Can measures of prey availability improve our ability to predict the abundance of large marine predators? Oecologia 153:563-568

Yeiser BG, Heupel MR, Simpfendorfer CA (2008) Occurrence, home range and movement patterns of juvenile bull (Carcharhinus leucas) and lemon (Negaprion brevirostris) sharks within a Florida estuary. Mar Freshw Res 59: 489-501

> Yokota L, Lessa RP (2006) A nursery area for sharks and rays in Northeastern Brazil. Environ Biol Fishes 75:349-360

Submitted: October 8, 2009; Accepted: March 15, 2010

Proofs received from author(s): May 18, 2010 